\title{
Diagnostic Value of FTIR Spectroscopy, Metabolomic Screening and Molecular Genetics in Saliva for Early Detection of Oral Squamous Cell Carcinoma (OSCC)
}

\author{
Kalpani Senevirathna ${ }^{1}$, Nadeeka U Jayawardana ${ }^{2}$, Ruwan D Jayasinghe ${ }^{1,3}$, Bimalka Seneviratne ${ }^{4^{*}}$ and AG Unil \\ Perera $^{5,6^{*}}$ \\ ${ }^{1}$ Center for Research in Oral Cancer (CROC), Faculty of Dental \\ Sciences, University of Peradeniya, Peradeniya, Sri Lanka. \\ ${ }^{2}$ Department of Agricultural Biology, Faculty of Agriculture, \\ University of Peradeniya, Peradeniya, 20400, Sri Lanka. \\ ${ }^{*}$ Corresponding authors \\ Bimalka Seneviratne, Department of Pathology, Faculty of Medical Sciences, \\ University of Sri Jayewardenepura, Gangodawila, Nugegoda, 10100, Sri \\ Lanka, AG Unil Perera, Department of Physics and Astronomy, Georgia \\ State University, Atlanta, GA 30302, USA.
}

${ }^{3}$ Department of Oral Medicine and Periodontology, Faculty of Dental Sciences, University of Peradeniya, Peradeniya, 20400, Sri

Submitted:28 Feb2021;Accepted:05 March 2021;Published:15 March 2021 Lanka.

${ }^{4}$ Department of Pathology, Faculty of Medical Sciences, University of Sri Jayewardenepura, Gangodawila, Nugegoda, 10100, Sri Lanka.

${ }^{5}$ Department of Physics and Astronomy, Georgia State University, Atlanta, GA 30302, USA.

${ }^{6}$ Center for Diagnostics and Therapeutics, Georgia State University, Atlanta, GA 30303, USA.

Citation: Kalpani Senevirathna, Nadeeka U Jayawardana, Ruwan D Jayasinghe, Bimalka Seneviratne and AG Unil Perera (2021) Diagnostic Value of FTIR Spectroscopy, Metabolomic Screening and Molecular Genetics in Saliva for Early Detection of Oral Squamous Cell Carcinoma (OSCC). Medical \& Clinical Research 6(2): 435-454

\begin{abstract}
Oral cavity cancer (OCC) has become a prevalent malignancy worldwide. Despite, the current developments of diagnoses and therapies, the 5-year survival rate has persisted at a dismal of 50\% in recent decades. Histopathological evaluation remains the golden standard method for cancer detection. However, in some cases the histopathological assessment may not be able to give a definitive diagnosis due to pitfalls in the interpretation of biopsy samples. There are well identified benign conditions in the oral cavity that could mimic malignancy. Hence, it is a timely approach to understand the utility of other emerging techniques which could be used in conjunction with the histopathological assessment. Attenuated total reflection Fourier-transform infrared (ATR-FTIR) spectroscopy has been employed extensively to diagnose various diseases by determining the chemical and molecular alterations. As a cost-effective, minimally invasive or non-invasive and label-free, bio spectroscopic technique this could be developed into an excellent diagnostic tool in the years to come. Besides this, OCC is known to alter the composition of metabolites in saliva. Analysis of the metabolomics in saliva of OCC patients could provide additional information that would be useful to establish a panel of biomarkers with regard to early detection. Furthermore, the rising epidemiological significance underlines the requirement of a better understanding of molecular mechanisms and the recognition of extrapolative tumor markers. Thus, gene expression analysis plays a vital role in identifying those genes related to the progression of this disease. In here, we review the potential applications of FTIR analysis in disease detection and metabolomics in verifying FTIR spectral data. Moreover, the genetic and epigenetic anomalies in OSCC will be briefly discussed along with the salivary biomarkers enabling the detection of this disease.
\end{abstract}

Keywords: Attenuated Total Reflection- Fourier Transform Infrared (ATR-FTIR), Metabolites, Biomarkers, Histopathological Evaluation, Gene Expression Analysis 


\section{Introduction}

Oral cavity cancer (OCC) is among the most frequent malignancies worldwide, specifically in both developing and developed countries $[1,2]$. Oral squamous cell carcinoma (OSCC) is considered as the most common histology and the key etiological factors of OSCC are tobbacco smoking and alcohol consumption [3]. It possesses different levels of differentiation and a tendency for lymph node metastasis [4]. OCC is classified as head and neck cancers and the head and neck squamous cell carcinoma (HNSCC) is the $6^{\text {th }}$ to $9^{\text {th }}$ most common malignancy worldwide $[5,6]$. In some research articles, OSCCs are classified under oropharyngeal cancer (OPC) and these oropharyngeal squamous cell carcinoma (OPSCC) has been bewildered with OSCC. Collectively, OSCC affected 354,864 people and led to 177,384 deaths worldwide in 2018 [7]. The annual occurrence of OSCC is around 400,000 novel cases accounting for $2 \%$ of cancers in women and $4 \%$ of cancers in men [8-10] and about 145,000 deaths [http://globocan.iarc.fr/Pages/ summary_table_pop_sel.aspx]. Hence OCC on average has a $50 \%$ death rate.

OSCC is a preventable disease since tobacco smoking and alcohol consumption are the major risk factors and present in almost 90\% of the cases [11]. They have a synergistic effect on the development of cancers [12-14]. Studies have revealed the association of the products of betel quid in the development of OSCC and the association of tobacco chewing with OSCC and Oral Potentially Malignant Disorders (OPMD) namely erythroplakia, Oral leukoplakia (OLK) and oral submucous fibrosis [15]. In addition to this, a variety of suspected risk factors including chronic irritation, poor oral hygiene, viral infections, occupational exposure, malnutrition along with low fruit and vegetable consumption and genetic factors have been identified for the development of OSCC $[16,17]$.

Conventional visual and tactile examination (CVTE) is used to adequately visualized OSCC but the precise diagnosis of subtle symptoms of early stages and inflammatory lesions are still difficult to detect [18]. This resulted in the diagnosis in advanced stages with low prognosis despite the developments in the treatments, which have resulted in an overall 5-year survival rate of approximately $50 \%$ [8, 19-22]. Histomorphological assessment is the golden standard method for the identification of malignant lesions but they are performed only when the cancerous or pre-cancerous lesions are visible and contain substantial genetic alterations. Furthermore, these tissue biopsies stipulate information which only related to a limited portion of a tumor and at a specific time-point. But liquid biopsy which founded on various body fluids is considered as a novel perspective in cancer diagnosis as it is capable in providing information at successive time points on circulating tumor cells, molecules like DNA/RNA and extracellular microvesicles which indicate the plasticity of tumors $[23,24]$. Therefore, saliva can be used as a promising biofluid for the early detection of biomarkers for both local and systemic diseases. Most importantly saliva possesses the advantages of accessibility and repeatability that it reduces the need for invasive and painful techniques or advanced/ sophisticated technical devices [25-27].

As histomorphological assessment is an invasive, time-consuming and a subjective technique, novel techniques are mandatory to detect the malignancies at an early stage. Thus, ATR/FTIR spectroscopy has become indispensable for the detection and the characterization of the molecular components of biological processes underlying OSCC and to identify those that play vital roles for the dynamic properties of tumor progression. The phenomenon behind this is the absorption of IR radiation by vibrational transitions in covalent bonds and it permits molecular imaging of complex biological samples [28]. The biochemical changes are associated with the morphological changes, symptomatic appearances, disease progression or treatment responses [29]. Rather than assessing the morphological differences, it analyses tissue samples at the molecular level before the morphological alterations arise [30].

Salivary biomarkers for OSCC detection, mRNA, proteins and microRNA have revealed potential to be clinically significant [3134]. Salivary metabolomics is also developing to diagnose OSCC along with Sjogren's syndrome and OLK. The usage of salivary metabolites is trustworthy because these molecules might be transferred into saliva by many cells, such as tumor cells, in the oral cavity and the salivary glands. However, there are several salivary metabolomic studies which simply detected the metabolomic phenotypes in saliva but did not uncover the underlying biological mechanisms behind it. Therefore, extensive analysis of the field of salivary metabolomics is extremely important for the detection of OSCC at early stages along with the molecular components and their respective mechanisms $[35,36]$.

Despite the advancement in the therapeutic and surgical treatments, survival period of OSCC at five years is the lowest among major cancers, and continue to remain unchanged in the past two decades. The development in the epidemiological relevance of OSCC highlights the requirement of a better understanding of the molecular mechanisms underlying it and to recognise predictive tumor markers and therapeutic targets [37]. The gap in the understanding of its aetiology and lack of drugable targets are the prime reasons for lack of success in efficient treatments. Concentrating on this issue necessitates a large-scale analysis of gene expression profiles [38]. DDRT-PCR (Differential display reverse transcription-polymerase chain reaction) is an essential approach in this regard. It is capable to randomly sample the transcriptome and not constrained to a pre-defined set of genes like microarrays. And these cellular genes could precisely serve as predictive molecular markers for OSCC detection at early stages [39]. In this review, we focused on the capability of ATR/FTIR spectroscopy as a diagnostic tool for the detection of cancers and particular focus will also be given to verify the findings of ATR/FTIR spectroscopy using salivary metabolomics. Moreover, genetic and epigenetic anomalies of OSCC will be briefly discussed along with the salivary biomarkers which capable in detecting this disease.

\section{Techniques Used to Detect Cancer}

In today's time, the cancers are mainly diagnosed through the microscopic evaluation of stained tissue samples by pathologists. These professionals observed certain samples only when cancerous or pre-cancerous lesions are observable and already contain significant genetic changes. Use of the histopathological diagnosis in cancer detection is time-consuming and invasive and the sensitiveness of the technique is heavily depending on 
the subjective judgement made by the pathologists which lead to intra and inter-observer variations. On that account, misdiagnosis with high false negative and false positive rates are commonly observable [22]. In some instances, which accounts for about $10 \%$ of the pathological evaluation could not result in a firm diagnosis about the tumors. It is because of overlapping of histological features or that the tumor was poorly differentiated and the origin could not be identified [40]. Histopathological diagnosis requires a complex process of histochemical staining using different dyes, out of which the hematoxylin and eosin (H\&E) has been the widely accepted routine staining method [41]. Apart from the histomorphological analysis, Toluidine blue (TB) staining method has been employed as a diagnostic aid in identifying high-risk OPMDs and early asymptomatic OSCCs. Majority of OSCC is headed by OPMDs, therefore identifying them at an early stage is significant in the management of this disease [42]. Varying degree of sensitivity and specificity for the detection of OPMD and OSCC using this test has been reported in the literature. Among them, a study conducted in India indicates $86.36 \%$ and $76.9 \%$ of sensitivity and specificity, respectively [43]. TB test has been proven to be effectively identifying satellite lesions but its reliability becomes questionable when detecting OPMD which exist as erosive or ulcerated lesions. Because it could lead to false-positive results as a result of false retention of stain in ulcerated and inflamed areas of the lesion $[44,45]$. Therefore, effective diagnosis of cancer required more specific, effective and precise methodologies.

\section{What is FTIR spectroscopy?}

FTIR spectroscopy is defined as a vibrational spectroscopic technique employed to optically probe the molecular alterations correlated with the diseased tissues [46-48]. This technique is used to scrutinize more conservative ways of analysis to determine characteristics within tumor samples and cells. It provides accurate and scrupulous assignment of the bonding types, functional groups and the molecular conformations. Spectral bands of the vibrational spectra are highly specific to the molecule and provide direct information regarding the biochemical composition $[49,50]$. Though, FTIR and Raman spectroscopy are pertinent techniques, with their respective spectra complementary to one another, there are some differences between the two techniques. A most prominent difference is the type of samples that can be analysed. FTIR primarily used to analyse no aqueous samples, whereas Raman spectroscopy is as effectual for aqueous samples. This is the main drawback of FTIR spectroscopy; that its strong absorption bands of water [51-53]. To overcome this, further sample preparation or extraction procedures are unnecessary, for the aqueous samples like saliva and blood, air drying of the samples will eliminate the strong water absorption regions of the spectrum [54].

FTIR spectroscopy is mainly used to characterize the molecular structures by chemists. However, this technique is being used for many decades to examine biological specimens as a cancer diagnostic tool [55]. This is a relatively simple, reproducible, reagent-free technique and most importantly non-destructive to the samples. Moreover, it requires nanograms to micrograms of the sample with minimal preparation and it possesses a greater sensitiveness to the chemical alterations which occurred during the transformation from normal to a pathological state or during the treatment, thereby it can assist the recognition of novel biomarkers correlated with the disease [56]. The signature spectral fingerprint of intensity peaks created by the FTIR spectroscopy elaborates the multiplex parameters of the genome, lipidome, proteome and metabolome of the biological sample analysed. Interestingly, the biochemical fingerprint alterations are unique to the molecular changes of specific diseases and it provides precise diagnostic information about the patient's health status. These biological substances absorb energy in the mid-IR region, from 4000 to $400 \mathrm{~cm}^{-1}$ of the electromagnetic spectrum. The fingerprint region $\left(1450-600 \mathrm{~cm}^{-1}\right)$ is considered as the typical spectral region use to examine these specimens. In addition to this, the amide I and II region (1700-1500 $\mathrm{cm}^{-1}$ ) also used for further examination. Lowerwavenumber regions are usually correlated with bending and carbon skeletal fingerprint vibrations, while higher-wavenumber region (3500-2550 $\left.\mathrm{cm}^{-1}\right)$ correspond to stretching vibrations including $\mathrm{C}-\mathrm{H}, \mathrm{O}-\mathrm{H}, \mathrm{N}-\mathrm{H}$ and $\mathrm{S}-\mathrm{H}$ bonds and this higher region is more prone to stronger moister absorption, thus signal to noise ratio is higher [57].

\section{FTIR Spectroscopy for Disease Detection}

FTIR spectroscopy seems to be the fastest-growing area in vibrational spectroscopy to the diagnosis of several cancers, including brain, breast, colorectal, endometrial, ovarian, prostate, skin and others. The IR fibre-optic probes equipped with ATR elements permit in vivo and in-situ diagnostic of easily reached organs including skin, oral cavity, colon and gastrointestinal tract through the colonoscopes and endoscopes $[58,59]$. Though many other pathological conditions have been extensively studied using this technique and a few examples of the wide-reaching 
applications of ATR-FTIR spectroscopy is briefed in Table 1.

Table 1: Summary of the pathological conditions and their respective biomarkers analysed by ATR/FTIR spectroscopy.

\begin{tabular}{|c|c|c|c|c|}
\hline Disease & Sample analysed & Spectral Biomarker & $\begin{array}{l}\text { Wavenumber } \\
\left(\mathrm{cm}^{-1}\right)\end{array}$ & References \\
\hline Rheumatoid arthritis & Blood serum samples & - & $3000-2800$ & {$[60]$} \\
\hline HIV/AIDS & Blood serum & $\begin{array}{c}\text { lipids/fatty acids } \\
\text { carbohydrates } \\
\text { glucose } \\
\text { proteins }\end{array}$ & $\begin{array}{c}3010 \\
1299 \text { and } 1498 \\
1035 \\
1600 \text { and } 1652\end{array}$ & {$[61]$} \\
\hline \multirow[t]{2}{*}{ Diabetes } & $\begin{array}{l}\text { Human fingernail } \\
\text { clippings }\end{array}$ & Glycation & $\begin{array}{l}\text { Increased absorption at } \\
1047\end{array}$ & {$[62]$} \\
\hline & Lip cells & $\mathrm{HbA1c}$ & $1300-1400$ & {$[63]$} \\
\hline Kidney diseases & Human serum samples & $\begin{array}{c}\mathrm{C}=\mathrm{O} \text { in creatinine } \\
(\text { Lactam }) \\
(\mathrm{C}=\mathrm{N}) \text { in creatinine } \\
\mathrm{C}=\mathrm{O} \text { and } \mathrm{NH}_{2} \text { in urea } \\
\mathrm{C}=\mathrm{O} \text { in urea } \\
\mathrm{N}-\mathrm{H} \text { in urea } \\
\mathrm{NH} \text { in creatinine } \\
\text { Aliphatic } \mathrm{CH}_{3} \text { in } \\
\text { creatinine } \\
\mathrm{C}-\mathrm{N} \text { in urea } \\
\mathrm{C}-\mathrm{C}-\mathrm{N} \text { in creatinine } \\
\mathrm{N} \text { in creatinine (amine) }\end{array}$ & $\begin{array}{l}1705-1725 \\
1690-1640 \\
1680-1620 \\
1670-1650 \\
1650-1620 \\
1565-1475 \\
1465-1440 \\
1420-1400 \\
1230-1100 \\
1000-1250\end{array}$ & {$[64]$} \\
\hline Alzheimer's disease & $\begin{array}{l}\text { Blood plasma and } \\
\text { cerebrospinal fluid } \\
\text { (CSF) }\end{array}$ & $\begin{array}{c}\text { Amyloid- } \beta \text { peptides, } \\
\beta \text {-sheet, amyloid- } \beta \\
\text { peptides }\end{array}$ & 1643 & {$[65]$} \\
\hline
\end{tabular}

\section{ATR-FTIR spectroscopy for cancer detection}

This technique has been used to analyse various biological samples to develop better alternatives for cancer diagnosis and management. Compared to other biological samples blood and tissue samples are generally used in current day clinical diagnostics for the diverse number of diseases [60-66]. Suitable sample types for ATR-FTIR spectroscopy including tissues, cells and biological fluids are summarized in Table 2.

Table 2: Different biological samples analysed by the ATR/ FTIR spectroscopy.

\begin{tabular}{|l|l|}
\hline Sample type & References \\
\hline Blood & {$[67-73]$} \\
\hline Tissues & {$[40,74-79]$} \\
\hline Extracellular vesicles (EVs) & {$[80-82]$} \\
\hline Urine & {$[83]$} \\
\hline Bladder wash & {$[84]$} \\
\hline Bile & {$[85]$} \\
\hline Sputum samples & {$[86,87]$} \\
\hline Saliva & {$[82,88,89]$} \\
\hline
\end{tabular}

A recent study by [82], revealed that the salivary exosomes of OSCC and healthy individuals (HI) displayed a peak of absorbance intensity at $1033 \mathrm{~cm}^{-1}$. The peak of absorbance intensity of $\mathrm{HI}$ exosomes in this region was considerably higher compared to OSCC [67-82]. Bands in this area are accountable for the vibrational modes of $-\mathrm{CH}_{2} \mathrm{OH}$ groups and the $\mathrm{C}-\mathrm{O}$ stretching vibration as well as $\mathrm{C}-\mathrm{O}$ bending vibrations of the $\mathrm{C}-\mathrm{OH}$ groups of different carbohydrates (i.e. glucose, fructose and glycogen) [83-91]. Salivary exosomes of HI and OSCC appeared to be have another peak of absorbance intensity at $1072 \mathrm{~cm}^{-1}$ where, OSCC being lower compared to HI [82]. This region is responsible for the symmetric stretching vibrations of the phosphodiester groups of nucleic acids (DNA and RNA) of the cell [90-92].

In addition to this, the spectral peaks at 2924 and $2854 \mathrm{~cm}^{-1}$ were observed in the HI exosomes, allied to the absorption bands of symmetric and asymmetric $\mathrm{C}-\mathrm{H}$ stretching vibrations of $\mathrm{CH}_{2}$ and $\mathrm{CH}_{3}$ methylene groups of fatty acids within the cellular membranes $[90,92]$. Salivary exosomes of OSCC displayed peaks in the same location; but, their intensity was lower compared to those of $\mathrm{HI}$ [82]. The band at $1743 \mathrm{~cm}^{-1}$ is accredited to the $\mathrm{C}=\mathrm{O}$ stretching vibration in lipids of the cell [90, 92, 93]. The HI exosomes displayed a peak of absorbance intensity at this wavenumber compared to OSCC [82]. The protein spectra were located in the region of $1300-1800 \mathrm{~cm}^{-1}$ wavenumbers [90]. Bands in this region 
signify primarily the amide II, probably accredited to the region of transmembrane proteins [94]. Generally, the absorbance spectrum of the OSCC exosomes has a higher intensity compared to the HI at this region. For OSCC exosomes, a peak was identified at 1543 $\mathrm{cm}^{-1}$, while the peak for the exosomes of HI was shifted slightly towards the right and being positioned at $1547 \mathrm{~cm}^{-1}$ [82]. The spectral peak at $1543 \mathrm{~cm}^{-1}$ is attributed to the amine II membrane proteins with oriented secondary structural components [94]. Salivary exosomes from OSCC patients displayed increased levels of these proteins compared to HI [82]. Another peak in the OSCC exosomes was observed at $1404 \mathrm{~cm}^{-1}$, which is responsible for the $\mathrm{C}-\mathrm{H}$ bending vibrations in acyl residues of lipids or amines $[90,92,95]$. Where, salivary exosomes of OSCC displayed a peak of absorbance intensity at this wavenumber compared to HI. For the exosomes of OSCC, the FTIR spectra were consistently contrasting from $\mathrm{HI}$ at certain wavenumbers including; $1072 \mathrm{~cm}^{-1}$ (nucleic acids), $2924 \mathrm{~cm}^{-1}, 2854 \mathrm{~cm}^{-1}$ (membranous lipids) and 1543 $\mathrm{cm}^{-1}$ (transmembrane proteins) [82]. The Principal component analysis-linear discriminant analysis (PCA-LDA) discrimination model properly categorised the samples with a specificity of $89 \%$, accuracy of $95 \%$ and sensitivity of $100 \%$. Moreover, Support vector machine (SVM) indicated a training accuracy of $100 \%$ and a cross-validation accuracy of $89 \%$. Ultimately, this flaunted the specific IR spectral signature for OSCC salivary exosomes, can be efficiently differentiated from $\mathrm{HI}$ exosomes based on identifying delicate alterations in the conformations of lipids, proteins and nucleic acids using ATR-FTIR spectroscopy [82].

Via ATR-FTIR spectroscopy, [88] examined saliva, from HI, breast cancer $(\mathrm{BC})$ patients and benign patients to discriminate $\mathrm{BC}$ from both benign disease and controls. The potential spectral biomarker at $1302.9-1433 \mathrm{~cm}^{-1}$ was capable of distinguishing between human BC and HI with sensitivity and specificity of $90 \%$ and $80 \%$, respectively. As well, it can differentiate $\mathrm{BC}$ from benign disease with sensitivity and specificity of $90 \%$ and $70 \%$, respectively [88]. Taking this into account the conventional approaches employed in clinical practice including mammography, ultrasound, and magnetic resonance imaging (MRI), show sensitivities of $67.8 \%$, $83 \%$, and $94.4 \%$ and specificities of $75 \%, 34 \%$, and $26.4 \%$, respectively [96]. Thus this indicate the potential capability of this technique in detecting $\mathrm{BC}$ with higher specificity and sensitivity. In addition to this, these results could improve the accuracy obtained for BC diagnosis [88]. FTIR spectroscopy permits the analysis of the entire biochemical signature including; carbohydrates, lipids, proteins and nucleic acids of a biological sample rather than focusing on a single specific protein as a biomarker [97]. Hence, the salivary ATR-FTIR spectra are exceedingly appropriate due to their speed, expediency and cost effectiveness, strappingly signifying this approach for BC screening [88].

As aware that higher absorbance of a particular spectral vibrational mode signifies the increase of a specific biomolecule [98]. The elevated absorbance levels of BC patients at the $1041 \mathrm{~cm}^{-1}$ wavenumber is resulted by the increased levels of $\mathrm{PO}_{2}^{-}$symmetric stretching vibrations $\left[v_{\mathrm{s}}\left(\mathrm{PO}_{2}^{-}\right)\right]$, which present in nucleic acids and glycogen. According to the previous studies which based on FTIR spectroscopy reported many alterations in the phosphate region, which correlate mainly with nucleic acids and carbohydrates [99]. The peak of absorbance intensities in the $1433-1302.9 \mathrm{~cm}^{-1}$ region is mainly due to increased levels of $\mathrm{COO}^{-}$symmetric stretching vibrations $\left[v_{\mathrm{s}}\left(\mathrm{COO}^{-}\right)\right]$, of proteins and lipids. It is believed that, the higher expression of $\mathrm{PO}_{2}^{-}$symmetric stretching vibrations $[v$ $\left.\left(\mathrm{PO}_{2}^{-}\right)\right]$and $\mathrm{COO}^{-}$symmetric stretching vibrations $\left[v_{\mathrm{s}}\left(\mathrm{COO}^{-}\right)\right]^{\mathrm{s}}$ might be due to these molecules which initiated from blood and access to saliva by passive diffusion of lipophilic molecules (i.e. steroid hormones) or by active transport of proteins via ligandreceptor binding [100]. Henceforth, saliva may contain biomarkers that reflect the pathophysiological condition of the body, such as, BC. There are number of putative salivary molecular biomarkers that are most likely changed in the presence of $\mathrm{BC}$. And increased levels of certain proteins, carbohydrates and nucleic acids have been identified in the saliva of BC patients compared to the HI, which further corroborate with the findings of this study [86, 101104].

Plasma of prostate cancer (PC) patients has been studied with high throughput ATR-FTIR spectroscopy to reveal its potential in rapid and accurate diagnosis of the disease [73]. Where the FTIR spectra of plasma from $\mathrm{HI}$ indicates a peak of absorbance intensity at 1080 and $1240 \mathrm{~cm}^{-1}$ compared to the plasma spectrum from PC patients. The abovementioned two bands in this region are allied to the symmetric and asymmetric stretching vibrations of phosphodiester groups, respectively [105]. The increase intensity in the bands at 1120 and $1170 \mathrm{~cm}^{-1}$ are correlated with the carbohydrates. These bands showed a peak of absorbance intensity in plasma from HI compared to the PC patients. The protein spectra (region 1300 $1800 \mathrm{~cm}^{-1}$ ) were comparatively weak in the plasma from PC patients compared with that from HI [73]. The reduced protein content in the malignant tissues indicates an incited diversification of energy to accomplish increased energy requirement during the malignant stress of cells [106]. A decreased protein content was also observed in the FTIR spectra of serum from patients with lung cancer compared to HI [107]. The bands at $2800-3000 \mathrm{~cm}^{-1}$ and $1740-1750 \mathrm{~cm}^{-1}$ were decreased, indicating the reduction of lipids and fatty acids in the plasma from PC patients. This may be resulted due to the decreased levels of triglycerides and fat in the region of malignant tissue as a result of the increased demand of energy in the development and progression of the carcinoma [108]. Further, the partial least squares discriminant analysis (PLS-DA) model categorised FTIR spectra of plasma from $\mathrm{HI}$ and PC patients with a sensitivity and specificity of $99 \%$ and $98.4 \%$, respectively, and FTIR spectra of plasma from patients with different Gleason scores (GS) with a sensitivity and specificity ranging from $65 \%$ to $80 \%[73]$.

Using an ATR probe equipped with a diamond crystal, urine was examined toward differentiation of ovarian cancer (OVC) and endometrial cancer (ENC) patients from HI [83]. The spectral peaks that showed significant difference between ENC and $\mathrm{HI}$ were the: $1593 \mathrm{~cm}^{-1}(\mathrm{P}<0.0001,95 \% \mathrm{CI}=-0.0179$ to $-0.012), 1508 \mathrm{~cm}^{-1}(\mathrm{P}<0.0001,95 \%)$. Congruently, to ENC, the preponderance of the peaks indicates increased absorbance when OVC was present, despite the peak at $1597 \mathrm{~cm}^{-1}$. Only two out of the six discriminatory peaks had lower absorbances in ENC, these were accredited to $\mathrm{C}-\mathrm{C}$ vibrations of phenyl rings of the proteins $\left(\sim 1593 \mathrm{~cm}^{-1}\right.$, Amide II) and $\mathrm{CH}_{2}$ vibrations of lipids $\left(\sim 1462 \mathrm{~cm}^{-1}\right)$ [83]. This could be due to the elevated degradation of proteins along with the dwindled protein synthesis during cancer cachexia 
[109]. Another study also has implied that lipids and specifically cholesterol, were lower in blood samples of ENC than HI this possibly will explain the lower absorbance in the lipid region $\left(\sim 1462 \mathrm{~cm}^{-1}\right)$ of ENC patients [110]. When compare the OVC patients with $\mathrm{HI}$, the discriminatory peaks were primarily ascribed to proteins and nucleic acids. Elevated levels of these biomolecules were observed in OVC samples with an exemption of a peak 1597 $\mathrm{cm}^{-1}$ which was delegated to $\mathrm{C}-\mathrm{C}$ phenyl ring of proteins [83].

In this study, they have used three classification systems to calculate the diagnostic accuracy of spectroscopy to identify ENC and OVC. The optimal approach was PCA-SVM which recognised ENC with 95\% sensitivity, 95\% accuracy and 100\% specificity, OVC with $96.3 \%$ specificity, $100 \%$ sensitivity and $100 \%$ accuracy, which are remarkably high in comparison to the conventional molecular and imaging methods used in cancer detection [83]. The serum HE4 used for the ENC diagnosis possess a sensitivity and specificity of $45.4 \%$ and $95 \%$, respectively [111]. A combination of three different biomarkers including ApoA-1, prealbumin and transferrin is capable in differentiating healthy samples from early-stage ENC with sensitivity and specificity of $71 \%$ and $88 \%$, respectively along with that healthy samples from late-stage cancer with sensitivity and specificity of $82 \%$ and $86 \%$, respectively [83]. But the ultrasonography only managed to detect ENC with a sensitivity and specificity of $90-98 \%$ and $35-54 \%$, respectively [112]. MRI is capable of detecting early and advanced ENC with high sensitivity (87-100\%) and specificity (90-99\%) but stage Ic and II of the disease had considerably lower sensitivity (19-56\%) however the specificity endured to be higher (86-96\%) [113].

Serum CA-125 is currently use for the detection of OVC, achieve only a sensitivity of $50-60 \%$ for early stage of the disease and specificity of $>95 \%[114,115]$. Furthermore, the transvaginal ultrasound (TVS), computed tomography (CT), MRI and power Doppler are highly expensive and possesses a sensitivity $<90 \%$ for early OVC cases and have relatively high false positive fallouts which render them less beneficial for cancer screening [113]. Thus this indicate the efficacy of vibrational spectroscopy in diagnosing ENC and OVC from urine samples, with a higher accuracy. Being a simple, non-destructive, reagent free, label free and cost effective, biospectroscopic technique ATR/FTIR is considered as an ideal method for the detection of OVC and ENC and further improvement of the technique for larger population legions can make this the perfect cancer diagnostic tool for either a screening or diagnostic test for the years to come [83].

Paraffin-embedded tissue sections from 47 human subjects $(8 \mathrm{HI}$, 16 OLK, and 23 OSCC) has been studied with FTIR spectroscopy to identify spectral-biomarkers for the optimum diagnostic differentiation of OLK and OSCC [74]. A peak was observed at $1043 \mathrm{~cm}^{-1}$ (symmetric $\mathrm{PO}_{2}^{-}$stretching in RNA and DNA) for $\mathrm{HI}$ and OLK, while the peak of OSCC patients was shifted to $1050 \mathrm{~cm}^{-1}$ and the peak at $1109 \mathrm{~cm}^{-1}(v(\mathrm{CO}), v(\mathrm{CC})$ ring (polysaccharides, cellulose) was found to be reduce gradually in both OSCC and OLK $[74,116]$. In $\mathrm{HI}$ another peak was identified at $995 \mathrm{~cm}^{-1}$ which is due to the ring breathing but it was found to be absent in both OSCC and OLK. For HI a peak was observed at $1385 \mathrm{~cm}^{-1}$ (protein phosphorylation), while the peak of OLK and OSCC was slightly shifted towards right and been positioned at 1405 and $1406 \mathrm{~cm}^{-1}$ respectively. Again in $\mathrm{HI}$, there was a peak at $1550 \mathrm{~cm}^{-1}$ (Amide II), which moved to $1548 \mathrm{~cm}^{-1}$ for OLK and to $1543 \mathrm{~cm}^{-1}$ for OSCC [74]. The peaks at $1438 \mathrm{~cm}^{-1}$ and $1474 \mathrm{~cm}^{-1}$ in OSCC is resulted due to the changes in keratin expression [117]. There was an increased keratin deposition above the epithelium in OLK, and in OSCC distinct keratin pearls were observed [74].

During forward feature selection (FFS), 18 spectral wave numbers from the region $900-1800 \mathrm{~cm}^{-1}$, six each to differentiate HI vs. $\operatorname{OLK}\left(1628,1385,1088,1775,1704\right.$ and $\left.1662 \mathrm{~cm}^{-1}\right)$, HI vs. OCC $\left(1782,1713,1665,1545,1409\right.$ and $\left.1161 \mathrm{~cm}^{-1}\right)$ and OLK vs. OCC $\left(1032,956,1707,1639,1606\right.$ and $\left.1565 \mathrm{~cm}^{-1}\right)$ were identified. Further the six features acquired through FFS to discriminate $\mathrm{HI}$ and OSCC were the most significant, able to classify $\mathrm{HI}$ and OSCC with $81.3 \%$ sensitivity, $95.7 \%$ specificity and $89.7 \%$ of overall accuracy. The extracted features obtained by difference between mean spectra (DBMS) were also found to be highly significant, able to differentiate OLK and OSCC with $81.3 \%$ sensitivity, $91.3 \%$ specificity and $87.2 \%$ overall accuracy. Therefore, this study proves that features selected through FFS for HI and OSCC discrimination and through DBMS can be used as significant spectral biomarkers for the classification of highly associated OLK and OSCC [74].

Collectively considering various cancer types which have been analysed by ATR/FTIR indicate that certain spectral regions can be identified as biomarkers to diagnose cancer (Table 3). These results suggested that spectral signals accredited to the amide I/ II (secondary structure of the protein), carbohydrates and nucleic acid oscillations are sensitive to changes related to the cancer progression. It indicates that even though the sample type/cancer considered not largely affect the respective biomarker which can be used to specifically identify cancer but slight deviations of spectral regions depict that different cancer types have their identical spectral regions specific for them. Therefore, further analysis is extremely important to uncover these unique spectral biomarkers for each cancer type. 
Table 3: Summary of the different cancer types and their respective biomarkers analysed by ATR/FTIR spectroscopy.

\begin{tabular}{|c|c|c|c|c|c|c|c|c|c|c|}
\hline \multirow[t]{3}{*}{ Biochemical } & \multirow{3}{*}{$\begin{array}{c}\text { Wavenumber } \\
\left(\mathrm{cm}^{-1}\right)\end{array}$} & \multirow{3}{*}{$\begin{array}{c}\text { Band assignment and component } \\
\text { identified }\end{array}$} & \multicolumn{8}{|c|}{ Sample type } \\
\hline & & & \multicolumn{3}{|c|}{ Saliva } & \multirow{2}{*}{$\begin{array}{c}\begin{array}{c}\text { Blood } \\
1 \\
\text { serum }\end{array} \\
\text { PC } \\
\end{array}$} & \multicolumn{2}{|c|}{ Urine } & \multicolumn{2}{|c|}{ Tissue } \\
\hline & & & OCC 1 & OCC2 & BC & & OVC & ENC & OLK & OCC3 \\
\hline \multirow[t]{5}{*}{ Carbohydrate } & $905-1012$ & Carbohydrates/phospholipids & $\checkmark$ & $x$ & $x$ & $x$ & $x$ & $x$ & $x$ & $x$ \\
\hline & $1020-1050$ & $\begin{array}{l}v(\mathrm{C}-\mathrm{O}), \delta(\mathrm{C}-\mathrm{O}), v\left(\mathrm{CH}_{2} \mathrm{OH}\right) / v(\mathrm{C}-\mathrm{O}), \\
\rho_{\mathrm{b}}(\mathrm{C}-\mathrm{O}) \text { of the } \mathrm{C}-\mathrm{OH} \text { groups of } \\
\text { carbohydrates }(\text { glucose, fructose and } \\
\text { glycogen }) \text { or } v(\mathrm{C}-\mathrm{O}-\mathrm{O}-\mathrm{C}), v(\mathrm{C}-\mathrm{O}) \\
\text { coupled with } \rho_{\mathrm{b}}(\mathrm{C}-\mathrm{O}) \text { of } \mathrm{C}-\mathrm{OH} \text { of } \\
\text { carbohydrates or nucleic acid in } \\
\text { absence of glycogen }\left(v\left(\mathrm{PO}_{2}^{-}\right) \text {in RNA, }\right. \\
\text { DNA })\end{array}$ & $x$ & $\checkmark$ & $x$ & $\checkmark$ & $x$ & $x$ & $\checkmark$ & $\checkmark$ \\
\hline & $1109 / 1110$ & $\begin{array}{l}v(\mathrm{CO}), v(\mathrm{CC}) \text { ring (polysaccharides, } \\
\text { cellulose) }\end{array}$ & $x$ & $x$ & $x$ & $x$ & $x$ & $x$ & $\checkmark$ & $\checkmark$ \\
\hline & $1120-1170$ & $v(\mathrm{C}-\mathrm{O})$ and $v(\mathrm{C}-\mathrm{O}-\mathrm{C})$ & $x$ & $x$ & $x$ & $\checkmark$ & $x$ & $x$ & $x$ & $x$ \\
\hline & $1159-1174$ & $\begin{array}{l}v(\mathrm{C}-\mathrm{O}) \text { of proteins and carbohydrates } \\
\&\left(v_{\text {as }}(\mathrm{CO}-\mathrm{O}-\mathrm{C}) \text { Protein/Carbohydrate/ }\right. \\
\text { Lipid }\end{array}$ & $x$ & $x$ & $\checkmark$ & $x$ & $x$ & $x$ & $x$ & $x$ \\
\hline \multirow[t]{8}{*}{ Nucleic acids } & 878 & $\mathrm{C}_{3}$, endo/anti A-form helix & $x$ & $x$ & $\checkmark$ & $x$ & $x$ & $x$ & $x$ & $x$ \\
\hline & $925-929$ & Left-handed helix DNA (Z form) & $x$ & $x$ & $x$ & $x$ & $x$ & $x$ & $\checkmark$ & $\checkmark$ \\
\hline & 995 & $\begin{array}{l}v(\mathrm{C}-\mathrm{O}) \text { of ribose } / v(\mathrm{C}-\mathrm{C}) \text { of uracil ring } \\
\text { of RNA }\end{array}$ & $x$ & $x$ & $\checkmark$ & $x$ & $x$ & $x$ & $x$ & $x$ \\
\hline & 1116 & $v_{\mathrm{s}}(\mathrm{P}-\mathrm{O}-\mathrm{C}), v_{\mathrm{s}}(\mathrm{C}-\mathrm{O}(\mathrm{H}))$ of RNA & $x$ & $x$ & $x$ & $x$ & $x$ & $x$ & $x$ & $x$ \\
\hline & $1040-1100$ & $\begin{array}{l}v_{\mathrm{s}}\left(\mathrm{PO}_{2}^{-}\right) \text {of nucleic acids, phospholipids } \\
\text { and } v_{(\mathrm{C}-\mathrm{O}) \text { of saccharides }}\end{array}$ & $\checkmark$ & $\checkmark$ & $\checkmark$ & $\checkmark$ & $\checkmark$ & $\checkmark$ & $x$ & $x$ \\
\hline & $1220-1240$ & $\begin{array}{l}v_{\text {as }}\left(\mathrm{PO}_{2}^{-}\right) / \text {Phosphodiester region and } \\
v_{\text {as }}\left(\mathrm{PO}_{2}^{-}\right) \text {of the phosphate group of } \\
\text { phospholipids }\end{array}$ & $\checkmark$ & $x$ & $\checkmark$ & $\checkmark$ & $x$ & $x$ & $\checkmark$ & $\checkmark$ \\
\hline & 1373 & $v(\mathrm{C}-\mathrm{N})$ of cytosine, guanine & $x$ & $x$ & $x$ & $x$ & $\checkmark$ & $x$ & $x$ & $x$ \\
\hline & 2922 & $v_{\text {as }}\left(\mathrm{CH}_{2}\right)$ of lipids and nucleic acid & $x$ & $x$ & $\checkmark$ & $x$ & $x$ & $x$ & $x$ & $x$ \\
\hline \multirow[t]{9}{*}{ Proteins } & $1160 / 1 / 2$ & $\begin{array}{l}v(\mathrm{C}-\mathrm{O}), v(\mathrm{C}-\mathrm{O}-\mathrm{H}) \text { of serine, threonine, } \\
\text { tyrosine or } \gamma(\mathrm{C}-\mathrm{C}), \rho_{\mathrm{b}}(\mathrm{C}-\mathrm{OH}), v(\mathrm{C}-\mathrm{O}) \\
\text { of polysaccharides or RNA ribose or } \\
\text { Protein phosphorylation }\end{array}$ & $\checkmark$ & $x$ & $x$ & $x$ & $x$ & $x$ & $\checkmark$ & $\checkmark$ \\
\hline & $1220-1350$ & Amide III & $\checkmark$ & $x$ & $\checkmark$ & $\checkmark$ & $\checkmark$ & $\checkmark$ & $x$ & $x$ \\
\hline & $1404 / 5 / 6$ & $\rho_{\mathrm{b}}\left(\mathrm{CH}_{3}\right)$ & $\checkmark$ & $\checkmark$ & $\checkmark$ & $x$ & $\checkmark$ & $\checkmark$ & $\checkmark$ & $\checkmark$ \\
\hline & $\begin{array}{l}1438 \text { and } \\
1474\end{array}$ & $\rho_{\text {bas }}\left(\mathrm{CH}_{2}\right)$ of Keratin & $x$ & $x$ & $x$ & $x$ & $x$ & $x$ & $x$ & $\checkmark$ \\
\hline & $1449-1451$ & $\rho_{\mathrm{b}}\left(\mathrm{CH}_{3}\right) / \delta_{\mathrm{s}}\left(\mathrm{CH}_{3}\right)$ & $\checkmark$ & $x$ & $\checkmark$ & $\checkmark$ & $x$ & $x$ & $x$ & $x$ \\
\hline & 1458 & $\rho_{\text {bas }}\left(\mathrm{CH}_{3}\right)$ of Collagen & $x$ & $x$ & $x$ & $x$ & $x$ & $x$ & $\checkmark$ & $\checkmark$ \\
\hline & $1480-1600$ & Amide II & $\checkmark$ & $\checkmark$ & $\checkmark$ & $\checkmark$ & $\checkmark$ & $\checkmark$ & $\checkmark$ & $\checkmark$ \\
\hline & 1515 & Tyrosine ring & $\checkmark$ & $x$ & $x$ & $x$ & $x$ & $x$ & $x$ & $x$ \\
\hline & 1543 & Transmembrane proteins & $x$ & $\checkmark$ & $x$ & $x$ & $x$ & $x$ & $x$ & $x$ \\
\hline
\end{tabular}




\begin{tabular}{|c|c|c|c|c|c|c|c|c|c|c|}
\hline & 1650 & Amide I & $\checkmark$ & $x$ & $\checkmark$ & $\checkmark$ & $x$ & $x$ & $\checkmark$ & $\checkmark$ \\
\hline & 3075 & Amide B & $\checkmark$ & $x$ & $x$ & $x$ & $x$ & $x$ & $x$ & $x$ \\
\hline & $3295-3328$ & Amide A & $\checkmark$ & $x$ & $x$ & $\checkmark$ & $x$ & $x$ & $x$ & $x$ \\
\hline \multirow[t]{7}{*}{ Lipids } & 1320 & Fatty acids and amino acids, collagen & $x$ & $x$ & $x$ & $x$ & $x$ & $x$ & $\checkmark$ & $\checkmark$ \\
\hline & 1462 & $\mathrm{CH}_{2}$ vibrations & $x$ & $x$ & $x$ & $x$ & $x$ & $\checkmark$ & $x$ & $x$ \\
\hline & $1600-1800$ & $\begin{array}{l}v(\mathrm{C}=\mathrm{O}) \text { of fatty acids, triglycerides and } \\
\text { cholesterol esters }\end{array}$ & $x$ & $\checkmark$ & $x$ & $\checkmark$ & $x$ & $x$ & $x$ & $x$ \\
\hline & $2800-2965$ & $\begin{array}{l}v_{\mathrm{s}}\left(\mathrm{CH}_{2}\right) \text { of lipids and } v_{\mathrm{as}}\left(\mathrm{CH}_{2}\right) / v_{\mathrm{s}}\left(\mathrm{CH}_{2}\right) \\
\text { of } \mathrm{CH}_{2} \text { and } \mathrm{CH}_{3} \text { groups of fatty } \\
\text { acids (within cellular membranes), } \\
\text { triglycerides and proteins }\end{array}$ & $\checkmark$ & $\checkmark$ & $x$ & $\checkmark$ & $x$ & $x$ & $x$ & $x$ \\
\hline & 2873 & $v_{\mathrm{s}}\left(\mathrm{CH}_{3}\right)$ of lipids and protein side chains & $\checkmark$ & $x$ & $\checkmark$ & $\checkmark$ & $x$ & $x$ & $x$ & $x$ \\
\hline & $2925-2936$ & $v_{\text {as }}\left(\mathrm{CH}_{2}\right)$ & $\checkmark$ & $\checkmark$ & $x$ & $\checkmark$ & $x$ & $x$ & $x$ & $x$ \\
\hline & 2959 & $v_{\text {as }}\left(\mathrm{CH}_{3}\right)$ of lipids, DNA, and proteins & $\checkmark$ & $x$ & $\checkmark$ & $x$ & $x$ & $x$ & $x$ & $x$ \\
\hline \multirow{3}{*}{$\begin{array}{l}\text { Phospholipids/ } \\
\text { fatty acids }\end{array}$} & $600-900$ & Out-of-plane bending vibrations of $\mathrm{C}-\mathrm{H}$ & $x$ & $x$ & $\checkmark$ & $x$ & $x$ & $x$ & $x$ & $x$ \\
\hline & 1341 & $\mathrm{CH}_{2}$ wagging/ $\rho_{\mathrm{b}}\left(\mathrm{CH}_{2}\right)$ & $\checkmark$ & $x$ & $x$ & $x$ & $x$ & $x$ & $x$ & $x$ \\
\hline & 1400 & $\begin{array}{l}v_{\mathrm{s}}\left(\mathrm{COO}^{-}\right) \text {of fatty acids and } \rho_{\mathrm{b}}\left(\mathrm{CH}_{3}\right) \text { of } \\
\text { proteins }\end{array}$ & $\checkmark$ & $x$ & $x$ & $x$ & $x$ & $x$ & $x$ & $x$ \\
\hline
\end{tabular}

OCC: Oral cavity cancer BC: Breast cancer PC: Prostate cancer OVC: Ovarian cancer ENC: Endometrial cancer OLK: Oral leukoplakia (Abbreviations: $v$, stretching; $\delta$, deformation; $\rho_{b}$, bending; as, asymmetric; s, symmetric). (OCC1 [118]; OCC2 [82]; BC [88]; PC [73]; OVC \& ENC [83]; OCC3 \& OLK [74]).

FTIR Spectroscopy as A Promising Tool for OSCC Detection Using Saliva Samples

It is evident from the spectra, that significant alterations in banding positions and relative intensities are correlated with the development of a tumor. Peaks observed at the spectral interval between 3600 and $3000 \mathrm{~cm}^{-1}$ derived from $\mathrm{C}-\mathrm{H}, \mathrm{O}-\mathrm{H}$ and $\mathrm{N}-\mathrm{H}$ stretching modes of proteins whereas, the sturdy band at $23286 \mathrm{~cm}^{-1}$ is due to amide A N-H stretching mode [116]. The band at $3073 \mathrm{~cm}^{-1}$ is ascribed to amide B $v(\mathrm{NH}) / v(\mathrm{CH})$ vibrations in proteins ( $\alpha$-amylase, albumin, cystains, mucins, proline-rich proteins, sIgA) [116-120]. Alternatively, the spectral region $3000-2800 \mathrm{~cm}^{-1}$ is rich in bands attributed to symmetric and asymmetric $\mathrm{CH}_{2}$ and $\mathrm{CH}_{3}$ stretching oscillations of lipid molecules [104, 116, 121, 122]. It has to be distinguished that the most obvious changes occur in the region between $\sim 900$ and $1300 \mathrm{~cm}^{-1}$. Nevertheless, some of the bands in this region may overlap. This fingerprint region is considered as a highly diagnostic region in assessing numerous cancer types [104, 116, 119, 121-124] (Figure 1) (Figure 2).

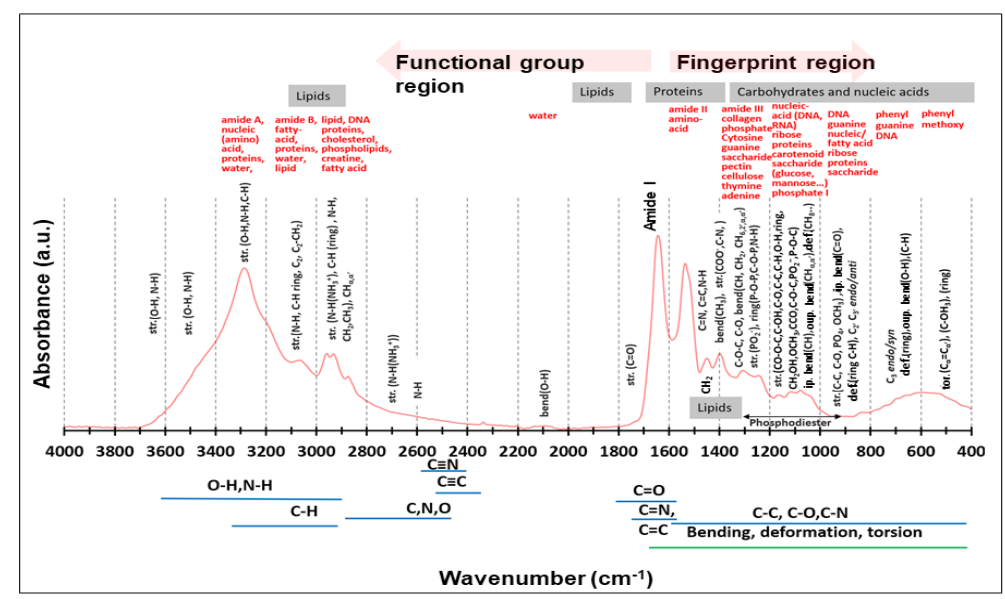

Figure 1: Typical normalized infrared spectrum from Dextran sodium sulphate (DSS) mice serum samples with biochemical assignments listed as, stretching vibration $(v)$ (str.); bending vibration $\left(\rho_{\mathrm{b}}\right)$ (bend); in-plane bending (ip. bend); out-plane bending (oup. bend); deformation $(\delta)$ (def.); torsion (tor.); $\mathrm{C}_{2}{ }^{\prime} / \mathrm{C}_{3}$ ' endo/anti (A/B-form helix) (endo/anti) conformation; guanine in a $\mathrm{C}_{3}$ ' endo/syn conformation in the $\mathrm{Z}$ conformation of DNA (endo/syn). 
Band resulted at $\sim 1078 \mathrm{~cm}^{-1}$ is allied to the asymmetric and symmetric $\mathrm{PO}_{2}^{-}$stretching from inorganic phosphates and $\mathrm{PO}_{4}^{3-}$ group of phospholipids $[125,126]$. This has shown that this spectral characteristic is correlated with the role of $\mathrm{PO}_{4}{ }^{3-}$ during the diseases [127]. Consequently, the extraordinary increase in $\sim 1074$ $\mathrm{cm}^{-1}$ band intensity of the tumor mixus (TM) compared to the HI, associated with the disease development [127-131]. According to, evident displacement of the band position from $1078 \mathrm{~cm}^{-1}$ in HI group to $1074 \mathrm{~cm}^{-1}$ for OSCC, validates the contribution of $\mathrm{PO}_{4}^{3-}$ upon the disease development. Apart from this, vibration comes from $\mathrm{PO}_{4}^{3-}$ group is recognised in the spectra at $\sim 1159,1239,985$, and $936 \mathrm{~cm}^{-1}$ [125] (Figure 2).

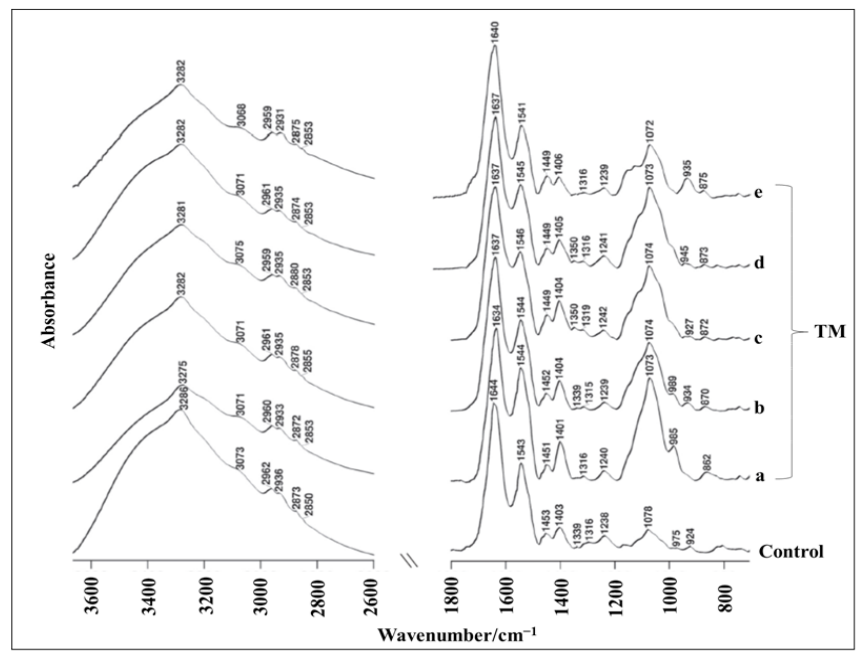

Figure 2: ATR-FTIR spectra of saliva samples: Control (spectrum averaged from five HI samples) and five salivary gland tumor (tumor mixus, TM) patients [118].

Besides, peaks obtained within 1000 to $1200 \mathrm{~cm}^{-1}$ spectral interval accredited to the $\mathrm{C}-\mathrm{O}$ stretching vibrations from carbohydrates. Accordingly, bands at $\sim 1021,1040$ and $1078 \mathrm{~cm}^{-1}$ instigate from sugar moieties (Figure 3d) [89, 128-130]. Though, most of the salivary proteins are glycosylated, these peaks can be ascribed to glycosylated $\alpha$-amylase, mucins or other sugar residues vibrations $[126,130-133]$. It has to be noted that band at $\sim 1119 \mathrm{~cm}^{-1}$ is due to the $v(\mathrm{C}-\mathrm{O})$ and $v(\mathrm{C}-\mathrm{O}-\mathrm{C})$ of carbohydrate vibrations in TM spectrum unveils significant enhancement in compared to HI group (Figure $3 \mathrm{~b}$ and d) $[116,134]$. Therefore, this spectral biomarker can be used to distinguish between the normal from cancer stages whereas, the $1119 \mathrm{~cm}^{-1}$ signal is reflected as a spectroscopic marker of TM [135]. Table 4 lists the most characteristic ATR-FTIR bands collectively with recommended band assignments for averaged spectra of HI and TM. By referring to the results obtained from these studies based on FTIR spectroscopy can be successfully used to differentiate $\mathrm{HI}$ from the TM, especially considering the spectral interval between 800 and $1300 \mathrm{~cm}^{-1}$ [118].

In addition to this, it evident significant alterations in the secondary structure of proteins (Figure 3) between the ATR-FTIR spectrum of HI and TM. It is worth pointing out that $\alpha$-helix maximum peak frequency decreased for the TM spectrum (1634-1640 $\mathrm{cm}^{-1}$; Figure 2a-e) in compared to the spectrum of HI $\left(1644 \mathrm{~cm}^{-1}\right.$; Figure 2 control) [118]. Concurrently, the $\beta$-sheet maximum band frequency $\left(1543 \mathrm{~cm}^{-1}\right.$; Figure 2 control) elevated for the TM patients (Figure 2a-e) $[104,116,119-122,130]$. Reason for this might be the variations in the extent of intermolecular $\mathrm{H}$ bond in $\alpha$-helical and $\beta$-sheet structures [136]. Moreover, the most intense band emerging at $1648 \mathrm{~cm}^{-1}$ accredited to $v(\mathrm{C}=\mathrm{O}),(\mathrm{CN})$ and $\delta(\mathrm{NH})$ vibrations from $\alpha$-helix. Deconvolution split resulted from two additional bands at 1664 and $1641 \mathrm{~cm}^{-1}$ as a result of the disordered structure-solvated $\left[v_{\mathrm{s}}(\mathrm{C}=\mathrm{O})\right]$ and unordered structure $[v(\mathrm{C}=\mathrm{O})]$, respectively (Figure $3 \mathrm{a}$ and $\mathrm{c}$ ). Apart from this, the content of $\alpha$-helical conformation was reduced noticeably for TM (Figure 3a and c; Table 4) [118]. It may be due to the development of $\beta$-sheet structures [137]. It is worthwhile to note that, the relative intensity of $1631 \mathrm{~cm}^{-1}$ band caused by the $\beta$-sheet structure $[v(\mathrm{C}=\mathrm{O}) / v(\mathrm{C}=\mathrm{C})]$ significantly decline upon the development of cancer [118]. Contrariwise, the $1615 \mathrm{~cm}^{-1}$ spectral signal attributed to the $\beta$-sheet formation $[v(C=C)]$ elevated considerably for TM spectral data [104, 116, 119-121, 130] (Figure 3a and c). It is worth mentioning that peaks originated at $\sim 1403\left[v_{\mathrm{s}}\left(\mathrm{COO}^{-}\right), \rho_{\mathrm{b}}\left(\mathrm{CH}_{3}\right)\right]$ and $1450 \mathrm{~cm}^{-1}\left[\rho_{\mathrm{b}}\left(\mathrm{CH}_{3}\right) / \delta\left(\mathrm{CH}_{2} / \mathrm{CH}_{3}\right)\right]$ reveal increased intensity for the TM (Figure 2). Besides this, the peak at $1543\left[\rho_{\mathrm{b}}(\mathrm{NH})\right.$, $v(\mathrm{CN})$, amide II], 1515 [trosine ring, $\alpha$-amylase, albumin, cystains, mucins, proline-rich proteins, sIgA $]$ and $1315 \mathrm{~cm}^{-1}[v(\mathrm{CN})$, $\rho_{\mathrm{b}}(\mathrm{NH})$, amide III ( $\alpha$-amylase, albumin, cystains, mucins, prolinerich proteins, $\operatorname{sig} A$ ) are prominent spectral features for proteins. These results undoubtedly evident that the secondary structure of proteins in HI samples vary largely from that in the TM samples [118] (Figure 3a and c).

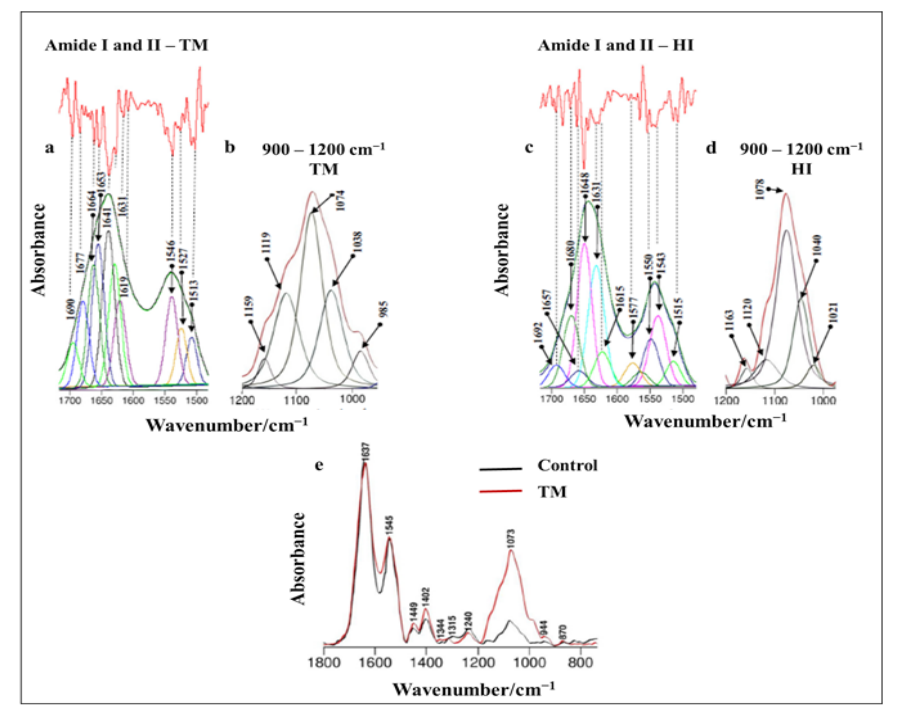

Figure 3: Curve-fitting analysis of amide I/II with second derivative spectra (a) and the $900-1200 \mathrm{~cm}^{-1}$ spectral interval (b) of TM patients and amide I/II with second derivative spectra (c) and the 900-1200 $\mathrm{cm}^{-1}$ spectral interval (d) of HI. (e) Averaged ATR-FTIR spectra of saliva samples from five $\mathrm{HI}$ and five salivary gland tumour patients [118]. 
Table 4: Wavenumber and suggested band assignments for averaged ATR-FTIR spectra of HI and TM [118].

\begin{tabular}{|c|c|c|c|c|}
\hline \multicolumn{2}{|c|}{ FTIR bands $\left(\mathrm{cm}^{-1}\right)$} & \multirow[t]{2}{*}{ Band assignment } & \multirow[t]{2}{*}{ Component identification } & \multirow[t]{2}{*}{ References } \\
\hline Control & TM & & & \\
\hline \multirow[t]{3}{*}{924} & \multirow[t]{3}{*}{936} & $v\left(\mathrm{PO}_{2}^{-}\right)$ & Inorganic phosphates & {$[125]$} \\
\hline & & $\delta(\mathrm{COH}), \delta(\mathrm{COC})$ & Carbohydrates & {$[116,123]$} \\
\hline & & $v_{\mathrm{as}}\left(\mathrm{CH}_{3}-\mathrm{N}\right)$ & Phospholipids & {$[116,123]$} \\
\hline 975 & 985 & $v\left(\mathrm{PO}_{2}^{-}\right)$ & Inorganic phosphates & {$[125]$} \\
\hline 1021 & & $v(\mathrm{CO}), \delta(\mathrm{C}-\mathrm{O}-\mathrm{H})$ & Glycosylated $\alpha$-amylase, mucins or other sugar residues & {$[116,125,126]$} \\
\hline 1040 & 1038 & $v(\mathrm{CO}), \rho_{\mathrm{b}}(\mathrm{C}-\mathrm{O}-\mathrm{H})$ & Glycosylated $\alpha$-amylase, mucins or other sugar residues & {$[116,125,126]$} \\
\hline \multirow[t]{6}{*}{1078} & \multirow[t]{6}{*}{1074} & $\mathrm{v}_{\mathrm{s}}\left(\mathrm{PO}_{2}^{-}\right)$ & Inorganic phosphates & {$[116,125,126]$} \\
\hline & & $v_{\mathrm{s}}\left(\mathrm{PO}_{2}^{-}\right), v_{\mathrm{as}}\left(\mathrm{PO}_{2}^{-}\right)$ & Phosphate group of phospholipids & $\begin{array}{l}{[89,104,116,121-} \\
124,138]\end{array}$ \\
\hline & & $v(\mathrm{CO}), \rho_{\mathrm{b}}(\mathrm{C}-\mathrm{O}-\mathrm{H})$ & Glycosylated $\alpha$-amylase, mucins or other sugar residues & {$[89,126,139]$} \\
\hline & & $v(\mathrm{C}-\mathrm{O}), \mathrm{v}(\mathrm{C}-\mathrm{O}-\mathrm{C})$ & Carbohydrates & {$[121,139]$} \\
\hline & & $\mathrm{v}_{\mathrm{as}}\left(\mathrm{PO}_{2}^{-}\right)$ & Inorganic phosphates & {$[116]$} \\
\hline & & $v(\mathrm{CO}), v(\mathrm{C}-\mathrm{O}-\mathrm{H})$ & Serine, threonine, tyrosine of proteins & {$[119,123,124]$} \\
\hline \multirow[t]{2}{*}{1239} & \multirow[t]{2}{*}{1243} & $\mathrm{v}_{\mathrm{as}}\left(\mathrm{PO}_{2}^{-}\right)$ & Phosphate group of phospholipids & {$[104,116,121,126]$} \\
\hline & & $v_{\mathrm{as}}\left(\mathrm{PO}_{2}^{-}\right)$ & Inorganic phosphates & {$[104,116,134]$} \\
\hline 1315 & 1315 & $v(\mathrm{CN}), \rho_{\mathrm{b}}(\mathrm{NH})$ & $\begin{array}{l}\text { Amide III ( } \alpha \text {-amylase, albumin, cystains, mucins, proline- } \\
\text { rich proteins, sIgA) }\end{array}$ & {$[116,119,121,123]$} \\
\hline 1341 & 1343 & $\rho_{\mathrm{b}}\left(\mathrm{CH}_{2}\right)$ & $\begin{array}{l}\text { Phospholipids, fatty acid, triglyceride, amino acid side } \\
\text { chains }\end{array}$ & {$[116]$} \\
\hline \multirow[t]{2}{*}{1407} & \multirow[t]{2}{*}{1403} & $v_{s}\left(\mathrm{COO}^{-}\right)$ & Fatty acids & {$[116,119,121,123]$} \\
\hline & & $\rho_{\mathrm{b}}\left(\mathrm{CH}_{3}\right)$ & Proteins & {$[104,116,124]$} \\
\hline 1451 & 1450 & $\rho_{\mathrm{b}}\left(\mathrm{CH}_{3}\right) / \delta\left(\mathrm{CH}_{2} / \mathrm{CH}_{3}\right)$ & Proteins/lipids & {$[104,116,121]$} \\
\hline 1515 & 1513 & Tyrosine ring & $\begin{array}{l}\text { Proteins ( } \alpha \text {-amylase, albumin, cystains, mucins, proline- } \\
\text { rich proteins, sIgA) }\end{array}$ & \multirow[t]{10}{*}{$\begin{array}{c}{[104,116} \\
119,120,122,123,130]\end{array}$} \\
\hline \multirow[t]{2}{*}{1543} & 1546 & $\rho_{\mathrm{b}}(\mathrm{NH}), v(\mathrm{CN})$ & Amide II & \\
\hline & 1527 & $\rho_{\mathrm{b}}(\mathrm{NH}), v(\mathrm{C}=\mathrm{N}), v(\mathrm{C}=\mathrm{C})$ & Amide II & \\
\hline 1615 & 1619 & $v(\mathrm{C}=\mathrm{C})$ & Amide I: $\beta$-sheet structure & \\
\hline 1631 & 1631 & $v(\mathrm{C}=\mathrm{O}) / v(\mathrm{C}=\mathrm{C})$ & Amide I: $\beta$-sheet structure & \\
\hline \multirow[t]{2}{*}{1648} & 1653 & $v(\mathrm{C}=\mathrm{O}), \delta(\mathrm{CN}), \delta(\mathrm{NH})$ & Amide I: $\alpha$-helix & \\
\hline & 1641 & $v(\mathrm{C}=\mathrm{O})$ & Amide I: unordered structure & \\
\hline \multirow[t]{2}{*}{1680} & 1677 & $v(\mathrm{C}=\mathrm{O})$ & Amide I: unordered random coils and turns & \\
\hline & 1664 & $v_{\mathrm{s}}(\mathrm{C}=\mathrm{O})$ & Amide I: disordered structure-solvated & \\
\hline 1692 & 1690 & $v(\mathrm{C}=\mathrm{O}), v(\mathrm{CN}), \rho_{\mathrm{b}}(\mathrm{NH})$ & Amide I: anti-parallel $\beta$-sheet & \\
\hline 2850 & 2851 & $v_{s}\left(\mathrm{CH}_{2}\right)$ & Lipids (cholesterol and mono/diglycerides of fatty acids) & \multirow{6}{*}{$\begin{array}{l}{[104,116,119-} \\
122,140,141]\end{array}$} \\
\hline 2873 & 2874 & $v_{s}\left(\mathrm{CH}_{3}\right)$ & Lipids, protein side chains & \\
\hline 2936 & 2935 & $\mathrm{v}_{\mathrm{as}}\left(\mathrm{CH}_{2}\right)$ & Lipids & \\
\hline 2962 & 2961 & $v_{\mathrm{as}}\left(\mathrm{CH}_{3}\right)$ & Lipids, protein side chains & \\
\hline 3073 & 3074 & $v(\mathrm{NH}) / v(\mathrm{CH})$ & $\begin{array}{l}\text { Amide B/ring ( } \alpha \text {-amylase, albumin, cystains, mucins, } \\
\text { proline-rich proteins, sIgA) }\end{array}$ & \\
\hline 3286 & 3282 & $\mathrm{v}_{\mathrm{as}}(\mathrm{NH})$ & Amide A & \\
\hline
\end{tabular}


Salivary metabolomics to verify ATR/FTIR Spectroscopic Findings

Metabolomics is referred as a novel promising "Omicsdiscipline" in systems biology, claiming to explore the entire set of metabolites exist in a biological system [142]. It is an analytical tool employed in conjunction with pattern recognition approaches and bioinformatics to distinguish metabolites and monitor their alterations in biofluids or tissues [143, 144]. Salivary metabolomics has become an emergent area in OSCC and OLK and beneficial to investigate these molecules which transported into saliva by different cells like tumors [145]. Interestingly, the results of salivary metabolomics further verify the findings of ATR/FTIR spectroscopy of different cancers. In which, the uncontrolled tumor growth is a characteristic feature of aggressive carcinogenesis, which depends on the nitrogen and carbon sources and energy to support dysregulated cancer cell progression [146, 147]. A study by [148]. revealed that, the three basic amino acids (histidine, lysine, and arginine) involve in the urea cycle and polyamine metabolism were found to be down regulated in OSCC. As mentioned by [149, 150], these pathways are not only providing profuse amount of nitrogen but also promotes hyperproliferative disorders in various cancers. This corroborate with the absorbance intensities of the protein spectra (region 1300-1800 $\mathrm{cm}^{-1}$ ) of the plasma of PC patients [73], urine of ENC patients [83] and serum of lung cancer patients [107] where it shows comparatively weak intensities indicating towards the increased consumption of proteins. But it is contrast with the findings of [82] for OSCC exosomes as it shows higher intensity for this region compared to HI.

Further, considerable alterations in the aminoacyl transfer RNA (tRNA) biosynthesis pathway highlights the dysregulation in mRNA translation for protein synthesis $[151,152]$. Moreover, the upregulation of ketoleucine, indole-acetate, and 3-hydroxyphenylacetate and down regulation of desaminotyrosine revealed abnormal metabolism of leucine, tryptophan, phenylalanine, and tyrosine, respectively [148]. Glutamine addition endorse the decrease in glutamine and associated elevation of glutamate by the process called glutaminolysis [153]. Reduced levels of glucose and elevated lactase suggests the on-going increased glycolysis [154]. This is further validated by the lower absorbance intensity at $1033 \mathrm{~cm}^{-1}$ (attributed to different carbohydrates including; glucose, fructose and glycogen $[90,91])$ in OSCC compared to HI [82] and the increased intensity in the bands at 1120 and $1170 \mathrm{~cm}^{-1}$ (allied with carbohydrates) in the plasma from HI compared to the PC patients suggesting the increased utilization of carbohydrates in cancer cells [73].

The energy fueling was affected by the changes in creatine metabolism (creatine, creatinine), acyl carnitine (acetyl carnitine, butyryl carnitine), free fatty acids (oleic acid, linoleic acid) and monoacyl glycerol [MG (20:4)] for mitochondrion $\beta$-oxidation [148]. As well, purine and pyrimidine metabolism pathways became abnormal in premalignant tumors, where the following metabolites were significantly changed (inosine, hypoxanthine, adenosine, thymidine, uridine, guanosine, cytosine), which are the building blocks for nucleotide replication in cell proliferation $[155,156]$. The lower absorbance intensity at $1072 \mathrm{~cm}^{-1}$ of salivary OSCC exosomes, 1080 (symmetric stretching vibrations of the phosphodiester groups of nucleic acids of the cell) and 1240 $\mathrm{cm}^{-1}$ (asymmetric stretching vibrations of phosphodiester groups) of serum of PC patients, suggest the increased utilization of nucleotides for the DNA replication and cell proliferation $[73,82]$. Moreover, the abnormalities in choline (choline, phosphocholine) and sphingolipid metabolism (sphingosine, phytosphingosine) indicating the dysregulation in cell proliferation $[157,158]$. The spectral bands at $1743 \mathrm{~cm}^{-1}(\mathrm{C}=\mathrm{O}$ stretching vibration in lipids of the cell [90-92]) shows peak intensity for salivary exosomes of $\mathrm{HI}$ compared to OSCC indicating the decreased levels of lipid in OSCC patients [82]. Further, the relatively lower absorbance of the plasma spectrum of PC patients in the regions of 2800-3000 $\mathrm{cm}^{-1}$ and $1740-1750 \mathrm{~cm}^{-1}$ [73] and lipid region $\left(\sim 1462 \mathrm{~cm}^{-1}\right)$ of ENC patients [83] signifying the increased utilization of lipids and fatty acids in cancerous cells.

This further validates the fact that findings of vibrational spectroscopy correlated with the salivary metabolomic studies. Thus salivary metabolomics can be considered as a method of verifying the FTIR spectroscopic findings. Moreover, it further proves that FTIR spectroscopy is a better approach for cancer diagnosis, screening, monitoring and management, but the challenge is to decipher this method in routine cancer diagnosis. Being a simple, non-invasive, inexpensive, biospectroscopic method ATR-FTIR spectroscopy can be a practical and most importantly a perfect diagnostic tool for the clinical practice. But the majority of these studies were conducted for smaller populations. Consequently, larger population-based clinical trials are extremely important to ascertain its utility in an actual clinical environment and to brighten the barriers in executing this technique and need to overcome them. To validate the technique mass patient legions with varying stages and different grades of cancer are highly compulsory [159].

Genetic and molecular alterations associated with OSCC The development of an OSCC involved multistep processes including the accumulation of multiple genetic alterations resulted by genetic predisposition and specific risk factors including alcohol consumption, chronic inflammation, and viral infections. Collectively, all these factors can lead to a wide range of genetic and molecular alterations. The alterations primarily influence two large groups of genes; oncogenes and tumor suppressor genes, which can be either inactivated or overexpressed through mutations, deletions, loss of heterozygosity ( $\mathrm{LOH}$ ), or epigenetic modifications such as methylation. The advancement in molecular biology helps better understanding of OCC and consequently aiding in the early diagnosis and together with development of novel personalized treatment methods. Carcinogenesis is a multistep process which is resulted due to both environmental and genetic factors [160]. In 1988 [161], mentioned about different mechanisms contributed in carcinogenesis of the oral mucosa and differentiated between two major groups; physical mechanisms, chemical mechanisms and viral mechanisms. Later [162], delineated six characteristic of cancer, which include acquisition of growth signalling autonomy (oncogenes), growth-inhibitory signals (tumor suppressor genes), evasion of apoptosis, cellular immortalization, angiogenesis, and ultimately, invasion and metastasis.

Apart from in situ hybridization, Southern and Northern blot analysis, PCR, and automatic DNA sequencing microarray technology is particularly beneficial for establishing general 
gene expression patterns and for screening for differential gene expression. However, the microarray results needed to be validated using an alternative method such as Northern blot analysis or quantitative real-time (RT) PCR. Currently, quantitative RT-PCR (qRT-PCR) is considered as the most reliable and reproducible gene quantification technique available and it is widely used for validating gene expression results acquired from microarray technology [163-165]. Over the past few years researches have combined DNA microarray hybridization with other molecular methods such as qRT-PCR to determine the gene expression in OSCC. Huge number of studies based on DNA microarray technology become successful in determining the gene expression profile of HNSCC and in OSCC in particular [160]. The majority of these studies have concluded that there is a possible correlation between different genes and OSCC. The possible functions of many genes have been already identified but still a gigantic repertoire of genes involved in this pathogenesis remains to be uncovered. Based on the results provided by the microarray studies, these novel genes can be investigated individually to reveal their function and the nature.

\section{Genetic and epigenetic anomalies in OSCC}

In this section, we have categorised the genetic and epigenetic abnormalities correlated with OSCC corresponding to the type of structure affected (chromosome, allele, oncogene, tumor suppressor gene or nucleotide) and the type of abnormalities (polymorphism, point mutation, deletion and other alterations) [160]. According to [166], numerous tumor suppressor genes including LRP1B, CASP8, CASP10, BARD1, ILKAP, PPP1R7, and $I N G 5$ get affected by the frequent chromosomal aberrations (deletions) at $2 \mathrm{q} 21-24,2 \mathrm{q} 33-35$, and $2 \mathrm{q} 37$. A recent paper by [167], revealed that loss of alleles 3 p14 and 9p21 occurs early in the development of OSCC and can even occur in simple keratosis. Furthermore, a high frequency of LOH at chromosomal loci 13q and $17 \mathrm{p}$ has been identified in OPMD and early carcinomas [168]. The region that affected by LOH possess essential genes. Also, chromosome 9 seems to be one of the regions that changed mostly and earliest in tumor development; allelic losses at 9p21 have been identified in the majority of OPMD and early OSCCs [169]. This region possesses genes which code for the cyclin dependent kinase inhibitors p16 and p14, two important regulators of cell proliferation. Additionally, 3p25, 3p21 and 3p13-14 regions of chromosome 3, comprise of chromosomal aberrations in OCC, though it is not yet confirmed which genes are affected [170]. Meanwhile, allelic losses at 5q21-22, 22q13, 4q, 11q, 18q and 21q are frequently found in correlated with advanced tumor stages and poorly differentiated carcinomas [171].

Abnormalities in certain oncogenes including ErbB1 (Her-1), $E r b B 2$, and $\mathrm{N}-, \mathrm{K}$ - and $\mathrm{H}$-ras have no significant role in OCC development [172-175]. Overexpression of CCND1, which encode for the synthesis of cyclin proteins, induce the cyclin D1 protein production, which has been related with poor prognosis in early-stage oral tumors [176-178]. Tumor suppressor gene abnormalities are also identified in malignant oral lesions. Where, OSCC are characterized by deviant expression of at least one of the members of the retinoblastoma ( $\mathrm{pRb}$ ) family of growth suppressor proteins. For an example, $C D K N 2 A$ encodes for the protein p16 which located at locus $9 \mathrm{p} 21$. This is considered as one of the most vulnerable areas of the human genome in OCC, meanwhile p14, the alternative transcript of the $C D K N 2 A$, is often deleted in malignant lesions in oral cavity. Furthermore, TP53 is considered as the most important tumor suppressor genes in human and the functions of this gene and its molecular system have been suppressed in many tumors, including OCC [179-181]. Moreover, three single nucleotide polymorphisms identified in the promoter region of the DNMT3B gene-C46359T [-149C $>\mathrm{T}],-238 \mathrm{~T}>\mathrm{C}$, and $-579>\mathrm{T}$ may possibly play a vital role in several cancers, including OSCC [182]. Also, the most common epigenetic change in DNA is methylation. Ras associated family genes (RASSF) were altered in OSCC. Particularly, they identified that RASSF 2 to be methylated in $26 \%$ of OSCC tumors examined [183]. In conclusion, oral carcinogenesis is a process which governs by multiple factors; involving various genetic processes that can amend the function of oncogenes, tumor suppressor genes and other molecules. These subsequent abnormalities can elevate the production of growth factors and several cell surface receptors thereby increase the transcription or levels of intracellular messenger factors. These alterations can sequentially lead to loss of tumor suppressor activity; thereby increase the cellular proliferation, weakening of the cell cohesion, invasion and metastasis [160].

\section{Salivary biomarkers for OSCC detection}

The genetic aberrations of cancer cells result altered gene expression patterns, which can be detected much before the resulting cancer phenotypes are established. Molecular biomarkers are these alterations that emerge exclusively or preferentially in cancer, compared with normal tissue of the same origin [184]. Accurate identification of such biomarkers can contribute to new avenues and establish major targets for early cancer detection and cancer risk assessment. Over the past few years, a large number of nucleic acid based biomarkers have been identified as novel and powerful tools for cancer detection [185-187]. However, many of them have been identified either in cancer cell lines or in biopsy specimens from late invasive and metastatic cancers. Still we are unable to succeed in detecting cancers at earliest stages with biomarkers [188-198].

Furthermore, the invasiveness of biopsies makes it unbefitting for cancer detection in high-risk populations. This suggests the requirement of developing novel diagnostic tools that can improve early cancer detection. The identification of molecular markers in body fluids previse the development of cancer in its earliest stage or in precancerous stages. On that account, saliva meets the requirements for highly effective, non-invasive and accessible diagnostic medium. A large amount of human RNA can be reliably detected in saliva initiate to a novel clinical approach, salivary transcriptome diagnostics [33]. Few salivary biomarkers for OSCC are summarised in Table 5.

Further studies are mandatory to identify whether the deviant expressions of these genes leads to the development of OSCC in human. Moreover, the biological significance of differential expression of such genes in head and neck/oral cancer should be investigated. Recognition of cancer-related genes that are unfailingly altered in cancer patients will provide information not only regarding the diagnostic markers but also intuitions about the molecular components involved in head and neck cancer 
development [33]. By these discoveries, it emphasizes that even though plentiful large-scale gene expression analyses have been conducted for OSCC, a gigantic repertoire of genes involved in this pathogenesis remains concealed. Functional significance of some of the genes mentioned are not yet recognised and further characterization is warranted in order to assess their potentiality as molecular markers and/or novel therapeutic targets.

\section{Table 5: Salivary biomarkers for OSCC detection}

\begin{tabular}{|c|c|c|c|c|c|}
\hline Gene & Gene name & Function & Locus & Gene expression & References \\
\hline$B 2 M$ & (2-microglobulin) & Anti-apoptosis; antigen presentation & $15 \mathrm{q} 21-\mathrm{q} 22.2$ & \multirow[t]{16}{*}{ Upregulated } & \multirow[t]{16}{*}{ [33] } \\
\hline DUSP1 & $\begin{array}{l}\text { Dual specificity } \\
\text { phosphatase } 1\end{array}$ & $\begin{array}{l}\text { Protein modification; signal } \\
\text { transduction; oxidative stress }\end{array}$ & $5 q 34$ & & \\
\hline FTH1 & $\begin{array}{l}\text { Ferritin, heavy } \\
\text { polypeptide } 1\end{array}$ & Iron ion transport; cell proliferation & $11 \mathrm{q} 13$ & & \\
\hline G0S2 & $\begin{array}{l}\text { (Putative } \\
\text { lymphocyte G0-G1 } \\
\text { switch gene) }\end{array}$ & $\begin{array}{l}\text { Cell growth and/or maintenance; } \\
\text { regulation of cell cycle }\end{array}$ & $1 \mathrm{q} 32.2-\mathrm{q} 41$ & & \\
\hline$G A D D 45 B$ & $\begin{array}{l}\text { Growth arrest and } \\
\text { DNA-damage- } \\
\text { inducible }\end{array}$ & Kinase cascade; apoptosis & $19 \mathrm{p} 13.3$ & & \\
\hline$H 3 F 3 A$ & $\begin{array}{l}\mathrm{H}_{3} \text { histone, family } \\
3 \mathrm{~A}\end{array}$ & DNA binding activity & $1 \mathrm{q} 41$ & & \\
\hline HSPC016 & \begin{tabular}{|l|l|} 
Hypothetical \\
protein HSPC016
\end{tabular} & Unknown & $3 \mathrm{p} 21.31$ & & \\
\hline IER3 & $\begin{array}{l}\text { Immediate early } \\
\text { response } 3\end{array}$ & $\begin{array}{l}\text { Embryogenesis; morphogenesis; } \\
\text { apoptosis; cell growth and } \\
\text { maintenance }\end{array}$ & $6 \mathrm{p} 21.3$ & & \\
\hline IL1B & Interleukin 1 & $\begin{array}{l}\text { Signal transduction; proliferation; } \\
\text { inflammation; apoptosis }\end{array}$ & $2 q 14$ & & \\
\hline IL8 & Interleukin 8 & $\begin{array}{l}\text { Angiogenesis; replication; calcium- } \\
\text { mediated signalling pathway; cell } \\
\text { adhesion; chemotaxis; cell cycle } \\
\text { arrest; immune response }\end{array}$ & $4 q 13-q 21$ & & \\
\hline$M A P 2 K 3$ & $\begin{array}{l}\text { Mitogen-activated } \\
\text { protein kinase } \\
\text { kinase 3 }\end{array}$ & $\begin{array}{l}\text { Signal transduction; protein } \\
\text { modification }\end{array}$ & $17 \mathrm{q} 11.2$ & & \\
\hline$O A Z 1$ & \begin{tabular}{|l} 
Ornithine \\
decarboxylase \\
antizyme 1
\end{tabular} & Polyamine biosynthesis & $19 \mathrm{p} 13.3$ & & \\
\hline PRG1 & $\begin{array}{l}\text { Proteoglycan } 1, \\
\text { secretory granule }\end{array}$ & Proteoglycan & $10 \mathrm{q} 22.1$ & & \\
\hline$R G S 2$ & $\begin{array}{l}\text { Regulator of } \\
\text { G-protein signalling } \\
2,24 \mathrm{kDa}\end{array}$ & $\begin{array}{l}\text { Oncogenesis; G-protein signal } \\
\text { transduction }\end{array}$ & $1 \mathrm{q} 31$ & & \\
\hline S100P & $\begin{array}{l}\text { S100 calcium } \\
\text { binding protein } \mathrm{P}\end{array}$ & $\begin{array}{l}\text { Protein binding; calcium ion } \\
\text { binding }\end{array}$ & $4 \mathrm{p} 16$ & & \\
\hline SAT & $\begin{array}{l}\text { Spermidine/ } \\
\text { spermine N1- } \\
\text { acetyltransferase }\end{array}$ & Enzyme, transferase activity & $\mathrm{Xp} 22.1$ & & \\
\hline
\end{tabular}




\begin{tabular}{|c|c|c|c|c|c|}
\hline GLTP & $\begin{array}{l}\text { Glycolipid transfer } \\
\text { protein }\end{array}$ & $\begin{array}{l}\text { Transfer various glycosphingolipids } \\
\text { (GSLs) through membranes and } \\
\text { involved as potential regulators } \\
\text { of cell processes mediated by the } \\
\text { GSLs. }\end{array}$ & $12 \mathrm{q} 24.11$ & & {$[188,189]$} \\
\hline ZKSCAN1 & $\begin{array}{l}\text { Zinc finger protein } \\
\text { with KRAB and } \\
\text { SCAN domains } 1\end{array}$ & $\begin{array}{l}\text { Suppress the transcription through } \\
\text { collaboration with transcriptional } \\
\text { intermediary factor } 1 \beta \text { (TIF1- } \beta \text { ) }\end{array}$ & $7 \mathrm{q} 22.1$ & & [190] \\
\hline$P C N A$ & $\begin{array}{l}\text { Proliferating Cell } \\
\text { Nuclear Antigen }\end{array}$ & $\begin{array}{l}\text { Co-factor of DNA polymerase } \\
\text { delta, is an essential component } \\
\text { of cellular DNA replication } \\
\text { mechanism. It works as a } \\
\text { loading clamp for the replication } \\
\text { machinery. }\end{array}$ & $20 \mathrm{p} 12.3$ & & [191] \\
\hline $\begin{array}{l}\text { DAPH1 or } \\
\text { mDial }\end{array}$ & $\begin{array}{l}\text { Diaphanous related } \\
\text { formin } 1\end{array}$ & Cytoskeletal remodelling & $5 q 31.3$ & & [192] \\
\hline TNKS2 & Tankyrase 2 & $\begin{array}{l}\text { Multifunctional protein and } \\
\text { overexpression of TNKS2 resulted } \\
\text { in a quick initiation of the necrotic } \\
\text { cell death }\end{array}$ & $10 \mathrm{q} 23.32$ & Down regulated & {$[193,194]$} \\
\hline$P A M$ & $\begin{array}{l}\text { Protein associated } \\
\text { with c-Myc }\end{array}$ & $\begin{array}{l}\text { A binding partner for c-Myc and } \\
\text { also regulates cAMP-mediated } \\
\text { signalling which in turn regulate } \\
\text { diverse cellular responses related to } \\
\text { cell communication }\end{array}$ & $5 q 21.1$ & & {$[195,196]$} \\
\hline$T U B B 2 C$ & $\begin{array}{l}\text { Tubulin beta 4B } \\
\text { class IVb }\end{array}$ & $\begin{array}{l}\text { Isotype of } \beta \text { - tubulin. However, } \\
\text { the functional significance of this } \\
\text { isotype is not known. }\end{array}$ & $9 q 34.3$ & & [37] \\
\hline$C L E C 3 B$ & $\begin{array}{l}\text { C-type lectin } \\
\text { domain family } 3 \\
\text { member B }\end{array}$ & Tissue modelling & $3 \mathrm{p} 21.31$ & & {$[197,198]$} \\
\hline
\end{tabular}

\section{Conclusion}

In conclusion, saliva can be considered as a first-line diagnostic tool to detect early stages of cancer. ATR-FTIR spectroscopy is efficacious for discriminating between $\mathrm{HI}$ and tumor samples. It has been illustrated the significant alterations in the secondary structure of proteins upon the development of cancer. FTIR imaging has the potential to stipulate information regarding the alterations befalls during cancer development but large scale studies are highly important to validate the technique as an effective cancer diagnostic tool. Salivary metabolomics illustrate its competence as a promising tool in the cancer detection and prediction of the disease but incompetence in revealing the stage of the disease. Moreover, salivary metabolomic study findings further verify the spectral biomarkers of ATR/FTIR spectroscopy. Which highlight the fact that, standardizing the protocol and surmounting the limitations will be useful to establish ATR/FTIR as a trustworthy, highly sensitive and a specific method of cancer detection. Moreover, several genes have been identified related to OSCC but there is a repertoire of genes involved in the pathogenesis that have not been disclosed yet. Molecular studies based on the gene expression are mandatory to uncover the molecular mechanisms behind the initiation, development and progression of the disease. To summarize, the purpose of our review is to make aware the readers about OSCC and to convey the emerging information regarding the novel and unconventional approaches in early detection of this disease based on salivary samples.

Acknowledgments: We are thankful to Hemendra Mani Ghimire at the Department of Physics and Astronomy, Georgia State University, Atlanta, GA 30303, USA for the contribution to the Figure 1.

\section{References}

1. Jemal A, Bray F, Center MM, Jacques Ferlay, Elizabeth Ward, et al. (2011) Global Cancer Statistics. Ca-Cancer J Clin 61: 69-90.

2. Siegel R, Naishadham D, Jemal A (2013) Cancer statistics. Ca-Cancer J Clin 63: 11-30.

3. Blot WJ, McLaughlin JK, Winn DM (1988) Smoking and drinking in relation to oral and pharyngeal cancer. Cancer Res 48: 3282-3287.

4. Barnes L (2005) Organization WH and Cancer IAfRo. Pathology and genetics of head and neck tumour. World Health Organization 2005.

5. Sun JR, Kim SM, Seo MH, Kim MJ, Lee JH, et al. (2012) OCA incidence based on annual cancer statistics in Korea. J Korean Assoc Oral Maxillofac Surg 38: 20-28.

6. Forman D, Bray F, Brewster DH, Mbalawa GC, Kohler B, et 
al. (2014) Cancer incidence in five continents Vol. X. Lyon: IARC Scientific Publication 164.

7. Ferlay JEM, Lam F, Colombet M (2020) Global cancer observatory: cancer today. Lyon, France: International Agency for Research on Cancer.

8. Jemal A, Siegel R, Ward E, Xu J, Thun MJ, et al. (2009) Cancer statistics. CA Cancer J Clin 59: 225-249.

9. Sidransky D (1995) Molecular genetics of head and neck cancer. Curr Opin Oncol 7: 229-233.

10. Vokes EE, Weichselbaum RR, Lippman SM, Hong WK (1993) Head and neck cancer. N Engl J Med 328: 184-194.

11. Dissanayaka WL, Pitiyage G, Kumarasiri PV, Liyanage RL, Dias KD, et al. (2012) Clinical and histopathologic parameters in survival of oral squamous cell carcinoma. Oral Surg Oral Med Oral Pathol Oral Radiol 113: 518-525.

12. Feller L, Chandran R, Khammissa RA, Meyerov R, Lemmer $\mathrm{J}$ (2013) Alcohol and oral squamous cell carcinoma. SADJ 68: $176-80$.

13. Marttila E, Uittamo J, Rusanen P, Lindqvist C, Salaspuro M, et al. (2013) Acetaldehyde production and microbial colonization in oral squamous cell carcinoma and oral lichenoid disease. Oral Surg Oral Med Oral Pathol Oral Radiol 116: 61-68.

14. Pelucchi C, Gallus S, Garavello W, Bosetti C, La Vecchia C (2006) Cancer risk associated with alcohol and tobacco use: focus on upper aero-digestive tract and liver. Alcohol Res Health 29: 193-198.

15. Warnakulasuriya S, Kujan O, Aguirre-Urizar JM, Bagan JV, González-Moles MÁ, et al. (2020) Oral potentially malignant disorders: A consensus report from an international seminar on nomenclature and classification, convened by the WHO Collaborating Centre for Oral Cancer. Oral Dis 2020.

16. Mehanna H, Paleri V, West CM, Nutting C (2011) Head and neck cancer-part1: epidemiology, presentation, and preservation. Clin Otolaryngol 36: 65-68.

17. Perry BJ, Zammit AP, Lewandowski AW, Bashford JJ, Dragovic AS, et al. (2015) Sites of origin of oral cavity cancer in non-smokers vs smokers: possible evidence of dental trauma carcinogenesis and its importance compared with human papillomavirus. JAMA Otolaryngol Head Neck Surg 141: 5-11.

18. Lingen MW (2010) Screening for oral premalignancy and cancer: what platform and which biomarkers. Cancer Prev Res 3: 1056-1059.

19. Carvalho AL, Pintos J, Schlecht NF, Oliveira BV, Fava AS, et al. (2002) Predictive factors for diagnosis of advanced-stage squamous cell carcinoma of the head and neck. AOHNS 128: 313-318.

20. Ishikawa S (2014) Acantholytic squamous cell carcinoma of the maxillary gingiva: A case report $\sim$ The third case of ASCC to affect the maxillirary gingiva. J Oral Maxillofac Surg Med Pathol 26: 488-491.

21. Ishikawa S, Kikuchi N, Kobayashi T, Yamanouchi H, Tachibana H, et al. (2013) Significant improvement in temporary dental rehabilitation by notable miniplate application in the hard palate for a patient with a large anterior maxillary defect: a case report/technique article. Head Face Med 9: 34.

22. Epstein JB, Zhang L, Rosin M (2002) Advances in the diagnosis of oral premalignant and malignant lesions. JCDA 68: 617-621.
23. Lousada-Fernandez F, Rapado-Gonzalez O, Lopez-Cedrun JL, Lopez-Lopez R, Muinelo-Romay L, et al. (2018) Liquid biopsy in oral cancer. Int J Mol Sci 19: 1704.

24. Wong DT, Nonaka T (2018) Liquid biopsy in head and neck cancer: promises and challenges. Crit Rev Oral Biol Med 97: 701-708.

25. Katsiougiannis S, Chia D, Kim Y, Singh RP, Wong DT (2017) Saliva exosomes from pancreatic tumor-bearing mice modulate NK cell phenotype and antitumor cytotoxicity. FASEB Journal 31: 998-1010.

26. Lau C, Kim Y, Chia D, Spielmann N, Eibl G, et al. (2013) Role of pancreatic cancer-derived exosomes in salivary biomarker development. J Biol Chem 288: 26888-26897.

27. Malamud D (2011) Saliva as a diagnostic fluid. Dent Clin N Am 55: 159-178.

28. Pallua JD, Pezzei C, Zelger B, Schaefer G, Bittner LK, et al. (2012) Fourier transform infrared imaging analysis in discrimination studies of squamous cell carcinoma. Analyst 137: 3965-3974.

29. Fan X (2003) Application of Fourier transform infrared spectroscopy in life science. J Life Sci 7: 83-87.

30. Su KY, Lee WL (2020) A review- Fourier Transform Infrared Spectroscopy as a Cancer Screening and Diagnostic Tool. A Review and Prospects. Cancers 12: 115-123.

31. Elashoff D, Zhou H, Reiss J, Wang J, Xiao H, Henson B, Wong, DTW (2012) Prevalidation of salivary biomarkers for OC detection. CEBP 2012: 664-672.

32. Gleber-Netto FO, Yakob M, Li F, Feng Z, Dai J, et al. (2016) Salivary Biomarkers for Detection of Oral Squamous Cell Carcinoma in a Taiwanese Population. Clin Cancer Res 22: 3340-3347.

33. Li Y, John MARS, Zhou X, Kim Y, Sinha U, et al. (2004) Salivary Transcriptome Diagnostics for Oral Cancer Detection. Clin Cancer Res 10: 8442-8450.

34. Park NJ, Zhou H, Elashoff D, Henson BS, Kastratovic DA, et al. (2009) Salivary microRNA: discovery, characterization, and clinical utility for OC detection. Clin Cancer Res 15: 5473-5477.

35. Sugimoto M, Wong DT, Hirayama A, Soga T, Tomita M (2010) Capillary electrophoresis mass spectrometry-based saliva metabolomics identified oral, breast and pancreatic cancer-specific profiles. Metabolomics 6: 78-95.

36. Wei J, Xie G, Zhou Z, Shi P, Qiu Y, et al. (2011) Salivary metabolite signatures of OC and leukoplakia. Int J Cancer 129: 2207-2217.

37. Chakraborty S, Nagashri MN, Mohiyuddin SMA, Gopinath KS, Kumar A (2010) Gene Expression Profiling of Oral Squamous Cell Carcinoma by Differential Display RT-PCR and Identification of Tumor Biomarkers. Indian J Surg Oncol 1: 284-293.

38. Sheu JJ, Hua CH, Wan L, Lin YJ, Lai MT, et al. (2009) Functional genomic analysis identified epidermal growth factor receptor activation as the most common genetic event in oral squamous cell carcinoma. Cancer Res 69: 2568-2576.

39. Lemaire F, Millon R, Young J, Cromer A, Wasylyk C, et al. (2003) Differential expression profiling of head and neck squamous cell carcinoma (HNSCC). Br J Cancer 89: 19401949.

40. Khanmohammadi M, Bagheri GA, Samani S, Ghasemi K, 
Ashuri A (2011) Application of linear discriminant analysis and Attenuated Total Reflectance Fourier Transform Infrared microspectroscopy for diagnosis of colon cancer. POR 17: 435-441.

41. Bergner N, Romeike BF, Reichart R, Kal R, Popp J, et al. (2013) Tumour margin identification and prediction of the primary tumour from brain metastases using FTIR imaging and support vector machines. Analyst 138: 3983-3990.

42. Jayasinghe RD, Hettiarachchi PVKS, Amugoda D, Kumaraarachchi M, Liyanage RLPR, et al. (2020) Validity of Toluidine Blue test as a diagnostic tool for high risk oral potentially malignant disorders- a multicentre study in Sri Lanka. J Oral Biol Craniofac Res 10: 547-551.

43. Neha V, Ravikiran A, Samatha V (2014) Chemiluminescence and toluidine blue as diagnostic tools for detecting early stages of oral cancer: an in vivo Study. J Clin Diagnostic Res 8: ZC35-ZC38.

44. Epstein JB, Oakley C, Millner A, Emerton S, van der Meij E (1997) The utility of toluidine blue as a diagnostic aid in patients previously treated for upper oropharyngeal carcinoma. Oral Surg Oral Med Oral Pathol Oral Radiol 83: 537-547.

45. Kumar GL, Kiernan JA (2010) Education Guide: Special Stains and H \& E, 2nd ed.; California: Dako North America.

46. Choo-Smith LP, Maquelin K, van Vreeswijk T, Bruining HA, Puppels GJ, et al. (2001) Investigating microbial (micro) colony heterogeneity by vibrational spectroscopy. Appl Environ Microbiol 67: 1461-1469.

47. Ellis DI, Goodacre R (2006) Metabolic fingerprinting in disease diagnosis: biomedical applications of infrared and Raman spectroscopy. Analyst 31: 875-885.

48. Kidder LH, Colarusso P, Stewart SA, Levin IW, Appel NM, et al. (1999) Infrared spectroscopic imaging of the biochemical modifications induced in the cerebellum of the Niemann-Pick type C mouse. J Biomed Opt 4: 7-13.

49. Hofman M, Pasieczna S, Wachowski L, Ryczkowski J (2006) Speciation of functional groups formed on the surface of carbonaceous materials modified by NO. J Phys IV France 137: 287-290.

50. Kang GS, Ko HJ, Choi CK (2003) Chemical bond structure of a-C: F films with a low dielectric constant deposited by using CH4/CF4 ICPCVD. JKPS 42: 676-681.

51. Fabian H, Jackson M, Murphy L, Watson PH, Fichtner I, et al. (1995) A comparative infrared spectroscopic study of human breast tumors and breast tumor cell xenografts. Biospectroscopy 1: 37-45.

52. Mandeville CW, Webster JD, Rutherford MJ, Taylor BE, Timbal A, et al. (2002) Determination of molar absorptivities for infrared absorption bands of $\mathrm{H}_{2} \mathrm{O}$ in andesitic glasses. Amer Miner 87: 813-821.

53. Seaman SJ, Dyar MD, Marinkovic N, Dunbar NW (2006) An FTIR study of hydrogen in anorthoclase and associated melt inclusions. Amer Miner 91: 12-20.

54. Paraskevaidi M, Martin-Hirsch PL, Martin FL (2018a) ATRFTIR Spectroscopy Tools for Medical Diagnosis and Disease Investigation. Nanotechnology Characterization Tools for Bio sensing and Medical Diagnosis. Springer 2018: 163-211.

55. Woernley DL (1952) Infrared absorption curves for normal and neoplastic tissues and related biological substances. Cancer Res 12: 516-523.
56. Le Naour F, Sandt C, Peng C, Trcera N, Chiappini F, et al. (2012) In situ chemical composition analysis of cirrhosis by combining synchrotron Fourier transform infrared and synchrotron X-ray fluorescence microspectroscopies on the same tissue section. Anal Chem 84: 10260-10266.

57. Walsh MJ, Singh MN, String HF, Pollock HM, Hammiche A, et al. (2008) FTIR microspectroscopy coupled with twoclass discrimination segregates markers responsible for interand intra-category variance in exfoliative cervical cytology. Biomark Insights 3: 179-189.

58. Mackanos MA, Contag CH (2010) Fiber-optic probes enable cancer detection with FTIR spectroscopy. Trends Biotechnol 28: 317-323.

59. Sahu R, Mordechai S (2005) Fourier transform infrared spectroscopy in cancer detection. Future Oncol 1: 635-647.

60. Lechowicz L, Chrapek M, Gaweda J, Urbaniak M, Konieczna I (2016) Use of Fouriertransform infrared spectroscopy in the diagnosis of rheumatoid arthritis: a pilot study. Mol Biol Rep 43: 1321-1326.

61. Sitole L, Steffens F, Krüger TPJ, Meyer D (2014) Mid-ATRFTIR spectroscopic profiling of HIV/AIDS sera for novel systems diagnostics in global health. Omics Int J Integr Biol 18: 513-523.

62. Coopman R, Van de Vyver T, Kishabongo AS, Katchunga P, Van Aken EH, et al. (2017) Glycation in human fingernail clippings using ATR-FTIR spectrometry, a new marker for the diagnosis and monitoring of diabetes mellitus. Clin Biochem 50: 62-67.

63. Yoshida S, Yoshida M, Yamamoto M, Takeda J (2013) Optical screening of diabetes mellitus using non-invasive Fouriertransform infrared spectroscopy technique for human lip. J Pharm Biomed 76: 169-176.

64. Khanmohammadi M, Garmarudi AB, Ramin M, Ghasemi K (2013) Diagnosis of renal failure by infrared spectrometric analysis of human serum samples and soft independent modeling of class analogy. Microchem J 106: 67-72.

65. Nabers A, Ollesch J, Schartner J, Kötting C, Genius J, et al. (2016) Amyloid- $\beta$-secondary structure distribution in cerebrospinal fluid and blood measured by an Immunoinfrared-sensor: a biomarker candidate for Alzheimer's disease. Anal Chem 88: 2755-2762.

66. Rahbarghazi R, Jabbari N, Sani NA, Asghari R, Salimi L, et al. (2019) Tumor-derived extracellular vesicles: Reliable tools for Cancer diagnosis and clinical applications. Cell Commun Signal 17: 73.

67. Backhaus J, Mueller R, Formanski N, Szlama N, Meerpohl H-G, et al. (2010) Diagnosis of breast cancer with infrared spectroscopy from serum samples. Vib Spectrosc 52: 173-177.

68. Lima KM, Gajjar KB, Martin-Hirsch PL, Martin FL (2015) Segregation of ovarian cancer stage exploiting spectral biomarkers derived from blood plasma or serum analysis: ATR-FTIR spectroscopy coupled with variable selection methods. Biotechnol Prog 31: 832-839.

69. Sheng D, Liu X, Li W, Wang Y, Chen X, et al. (2013a) Distinction of leukemia patients' and healthy persons' serum using FTIR spectroscopy. Spectrochim Acta A 101: 228-232.

70. Sheng D, Wu Y, Wang X, Huang D, Chen X, et al. (2013b) Comparison of serum from gastric cancer patients and from healthy persons using FTIR spectroscopy. Spectrochim Acta 
A 116: 365-369.

71. Zelig U, Mordechai S, Shubinsky G, Sahu, RK, Huleihel M, et al. (2011) Pre-screening and follow-up of childhood acute leukemia using biochemical infrared analysis of peripheral blood mononuclear cells. Biochim Biophys Acta Gen Subj 1810: 827-835.

72. Ghimire H, Garlapati C, Janssen EAM, Krishnamurti U, Qin G, et al. (2020) Protein Conformational Changes in Breast Cancer Sera Using Infrared Spectroscopic Analysis. Cancers 12: 1708.

73. Medipally DKR, Nguyen TNQ, Bryant J, Untereiner V, Sockalingum GD, et al. (2019) Monitoring Radiotherapeutic Response in Prostate Cancer Patients Using High Throughput FTIR Spectroscopy of Liquid Biopsies. Cancers 11: 925.

74. Banerjee S, Pal M, Chakrabarty J, Petibois C, Paul RR, et al. (2018) Fourier-transform-infrared spectroscopy based spectral-biomarker selection towards optimum diagnostic differentiation of oral leukoplakia and cancer. Anal Bioanal Chem 407: 7935-7943.

75. Baker MJ, Gazi E, Brown MD, Shanks JH, Clarke NW, et al. (2009) Investigating FTIR based histopathology for the diagnosis of prostate cancer. J Biophotonics 2: 104-113.

76. Großerueschkamp F, Kallenbach-Thieltges A, Behrens T, Bruning T, Altmayer M, et al. (2015) Marker-free automated histopathological annotation of lung tumour subtypes by FTIR imaging. Analyst 140: 2114-2120.

77. Kaznowska E, Depciuch J, Szmuc K, Cebulski J (2017) Use of FTIR spectroscopy and PCA-LDC analysis to identify cancerous lesions within the human colon. J Pharm Biomed Anal 134: 259-268.

78. Salman A, Sebbag G, Argov S, Mordechai S, Sahu RK (2015) Early detection of colorectal cancer relapse by infrared spectroscopy in "normal" anastomosis tissue. J Biomed Opt 20: 75007.

79. Yao H, Shi X, Zhang Y (2014) The use of FTIR-ATR spectrometry for evaluation of surgical resection margin in colorectal cancer: A pilot study of 56 samples. J Spectrosc 2014: 1-4.

80. Krafft C, Wilhelm K, Eremin A, Nestel S, von Bubnoff N, et al. (2017) A specific spectral signature of serum and plasma-derived extracellular vesicles for cancer screening. Nanomedicine 13: 835-841.

81. Yap XL, Ong TA, Lim J, Wood B, Lee WL (2019) Study of prostate cancer-derived extracellular vesicles in urine using IR spectroscopy. PDDBS 2: a0000026.

82. Zlotogorski Hurvitz A, Deke BZ, Malonek D, Yahalom R, Vered M (2019) FTIR-based spectrum of salivary exosomes coupled with computational-aided discriminating analysis in the diagnosis of oral cancer. J Cancer Res Clin Oncol 145: 685-694.

83. Paraskevaidi M, Morais CLM, Lima KMG, Ashton KM, String HF, et al. (2018b) Potential of mid-infrared spectroscopy as a non-invasive diagnostic test in urine for endometrial or ovarian cancer. Analyst 143: 3156-3163.

84. Gok S, Aydin OZ, Sural YS, Zorlu F, Bayol U, et al. (2016) Bladder cancer diagnosis from bladder wash by Fourier transform infrared spectroscopy as a novel test for tumor recurrence. J Biophotonics 9: 967-975.

85. Untereiner V, Sockalingum GD, Garnotel R, Gobinet C,
Ramaholimihaso F, et al. (2014) Bile analysis using highthroughput FTIR spectroscopy for the diagnosis of malignant biliary strictures: A pilot study in 57 patients. J Biophotonics 7: 241-253.

86. Lewis PD, Lewis KE, Ghosal R, Bayliss S, Lloyd AJ, et al. (2010) Evaluation of FTIR spectroscopy as a diagnostic tool for lung cancer using sputum. BMC Cancer 10: 640.

87. Menzies GE, Fox HR, Marnane C, Pope L, Prabhu V, et al. (2014) Fourier transform infrared for non-invasive optical diagnosis of oral, oropharyngeal, and laryngeal cancer. Am J Transl Res 163: 19-26.

88. Ferreira ICC, Aguiar EMG, Silva ATF, Santos LLD, CardosoSousa L, et al. (2020) Attenuated Total Reflection-Fourier Transform Infrared (ATR-FTIR) Spectroscopy Analysis of Saliva for Breast Cancer Diagnosis. J Oncol 2020: 1-11.

89. Bel'skaya LV, Sarf LV, Makarova NA (2018) Use of Fourier transform IR spectroscopy for the study of saliva composition. J Appl Spectrosc 85: 445-451.

90. Simonova D, Karamancheva I (2013) Application of Fourier transform infrared spectroscopy for tumor diagnosis. Biotechnol Biotechnol Equip 27: 4200-4207.

91. Zelig U, Mordechai S, Shubinsky G, Sahu RK, Huleihel M, et al. (2011) Pre-screening and follow-up of childhood acute leukemia using biochemical infrared analysis of peripheral blood mononuclear cells. Biochim Biophys Acta 1810: 827835.

92. Gao Y, Huo X, Dong L, Sun X, Sai H, et al. (2015) Fourier transform infrared microspectroscopy monitoring of 5-fluorouracil-induced apoptosis in SW620 colon cancer cells. Mol Med Rep 11: 2585-25891.

93. Li Q, Hao C, Kang X, Zhang J, Sun X, et al. (2017) Colorectal cancer and colitis diagnosis using Fourier transform infrared spectroscopy and an improved k-nearest-neighbor classifier. Sensors 17: 2739.

94. Dave N, Lorenz-Fonfria VA, Leblanc G, Padros E (2008) FTIR spectroscopy of secondary-structure reorientation of melibiose permease modulated by substrate binding. Biophys J 94: 3659-3670.

95. Christoua C, Agapioua A, Kokkinoftab R (2018) Use of FTIR spectroscopyand chemometrics for the classification of carobs origin. J Adv Res 10: 1-8.

96. Wang L (2017) Early diagnosis of breast cancer. Sensors 17: 1572 .

97. Zelig U, Barlev E, Bar O (2015) Early detection of breast cancer using total biochemical analysis of peripheral blood components: a preliminary study. BMC Cancer 15: 408.

98. Lewis PD, Lewis KE, Ghosal R (2010) Evaluation of FTIR Spectroscopy as a diagnostic tool for lung cancer using sputum. BMC Cancer 10: 640.

99. Zelig U, Barlev E, Bar O (2015) Early detection of breast cancer using total biochemical analysis of peripheral blood components: a preliminary study. BMC Cancer 15: 408.

100.Pfaffe T, Cooper-White J, Beyerlein P, Kostner K, Punyadeera C (2011) Diagnostic potential of saliva: current state and future applications. Clinical Chemistry 57: 675-687.

101.Brooks MN, Wang J, Li Y, Zhang R, Elashoff D, et al. (2008) Salivary protein factors are elevated in breast cancer patients. Molecular Medicine Reports 1: 375-378.

102. Streckfus C, Bigler L, Dellinger T, Dai X, Kingman A, et al. 
(2000) The presence of soluble c-erbB-2 in saliva and serum among women with breast carcinoma: a preliminary study. Clinical Cancer Research 6: 2363-2370.

103. Streckfus C, Bigler L, Tucci M, Thigpen JT (2017) preliminary study of CA15-3, c-erbB-2, epidermal growth factor receptor, cathepsin-D, and p53 in saliva among women with breast carcinoma. Cancer Investigation 18: 101-109.

104. Bellisola G, Sorio C (2012) Infrared spectroscopy and microscopy in cancer research and diagnosis. Am J Cancer Res 2: 1-21.

105. Banyay M, Sarkar M, Gräslund A (2003) A library of IR bands of nucleic acids in solution. Biophys Chem 104: 477-488.

106. Cazares LH, Adam BL, Ward MD (2002) Normal, benign, preneoplastic, and malignant prostate cells have distinct protein expression profiles resolved by surface enhanced laser desorption/ ionization mass spectrometry. Clin Cancer Res 8: 2541-2552.

107.Wang Q, Gao P, Cheng F (2014) Measurement of salivary metabolite biomarkers for early monitoring of oral cancer with ultra-performance liquid chromatography-mass spectrometry. Talanta 119: 299-305.

108. Li QB, Xu Z, Zhang NW (2005) In vivo and in situ detection of colorectal cancer using Fourier transform infrared spectroscopy. World J Gastroenterol 11: 327-330.

109. Smith K, Tisdale M (1993) Increased protein degradation and decreased protein synthesis in skeletal muscle during cancer cachexia. Br J Cancer 67: 680.

110. Swanson CA, Potischman N, Barrett RJ, Berman ML, Mortel $\mathrm{R}$, et al. (1994) Endometrial cancer risk in relation to serum lipids and lipoprotein levels. Cancer Epidemiol Biomarkers Prev 3: 575-581.

111. Moore RG, Brown AK, Miller MC, Badgwell D, Lu Z, Allard WJ, Granai C, Bast RC, Lu K (2008) Utility of a novel serum tumor biomarker HE4 in patients with endometrioid adenocarcinoma of the uterus. Gynecol Oncol 110: 196-201.

112. Timmermans A, Opmeer BC, Khan KS, Bachmann LM, Epstein E, et al. (2010) Endometrial thickness measurement for detecting endometrial cancer in women with postmenopausal bleeding: a systematic review and meta-analysis. Obstet Gynecol 116: 160-167.

113. Ortashi O, Jain S, Emannuel O, Henry R, Wood A, et al. (2008) Evaluation of the sensitivity, specificity, positive and negative predictive values of preoperative magnetic resonance imaging for staging endometrial cancer: a prospective study of 100 cases at the Dorset Cancer Centre. Eur J Obstet Gynecol Reprod Biol 137: 232-235.

114. Nossov V, Amneus M, Su F, Lang J, Janco JMT, et al. (2008) The early detection of ovarian cancer: from traditional methods to proteomics. Can we really do better than serum CA-125. J Obstet Gynecol 199: 215-223.

115. Yurkovetsky Z, Skates S, Lomakin A, Nolen B, Pulsipher T, et al. (2010) Development of a multimarker assay for early detection of ovarian cancer. J. Clin. Oncol 28: 2159-2166

116. Movasaghi Z, Rehman S, ur Rehman DI (2008) Fourier transform infrared (FTIR) spectroscopy of biological tissues. Appl Spectrosc Rev 43: 134-179.

117. Fukuyama Y, Yoshida S, Yanagisawa S, Shimizu M (1999) A study on the differences between oral squamous cell carcinomas and normal oral mucosas measured by Fourier transform infrared spectroscopy. Biospectroscopy 5: 117-126

118. Paluszkiewicz C, Pięta E, Woźniak M, Piergies N, Koniewska A, et al. (2020) Saliva as a first-line diagnostic tool: A spectral challenge for identification of cancer biomarkers. J Mol Liq 307: 112961.

119. Abbas S, Ozek NS, Emri S, Koksal D, Severcan M, et al. (2018) Diagnosis of malignant pleural mesothelioma from pleural fluid by Fourier transform-infrared spectroscopy coupled with chemometrics. J Biomed Opt 23: 105003.

120.Barth A (2007) Infrared spectroscopy of proteins. Biochim Biophys Acta Biomembr 1767: 1073-1101.

121. Caetano JrPC, Strixino JF, Raniero L (2015) Analysis of saliva by Fourier transform infrared spectroscopy for diagnosis of physiological stress in athletes. Open Biomed Eng J 31: 116124.

122. Sultana RR, Zafarullah SN, Kirubamani NH (2011) Saliva signature of normal pregnant women in each trimester as analysed by FTIR spectroscopy. Indian J Sci Technol 4: 481486.

123. Rodrigues LM, Magrini Alva TD, da Silva Martinho H, Almeida JD (2019a) Analysis of saliva composition in patients with burningmouth syndrome (BMS) by FTIR spectroscopy. Vib Spectrosc 100: 195-201.

124. Rodrigues RPCB, Aguiar EMG, Cardoso-Sousa L, Caixeta DC, Guedes CCFV, et al. (2019b) Differential molecular signature of human saliva using ATR-FTIR spectroscopy for chronic kidney disease diagnosis. Braz Dent J 30: 437-445.

125.Heise HM, Cocchieri L, Vahlsing T, Ihrig D, Elm J (2017) Monitoring of interstitial buffer systems using micro-dialysis and infrared spectrometry. In Proceedings of the SPIE 2017: $1-14$.

126.Heise HM, Marbach R (1998) Human oral mucosa studies with varying blood glucose concentration by non-invasive ATR-FT-IR-Spectroscopy. J Mol Cell Biol 44: 899-912.

127. Argov S, Ramesh J, Salman A, Goldstein J, Sinelnikov I, et al. (2002) Inflammatory bowel diseases as an intermediate stage between normal and cancer: a FTIR-microspectroscopy approach. J Biomed Opt 7: 1-7.

128. Giorgini E, Balercia P, Conti C, Ferraris P, Sabbatini S, et al. (2013) Insights on diagnosis of oral cavity pathologies by infrared spectroscopy: a review. J Mol Struct 1051: 226-232.

129. Sabbatini S, Conti C, Rubini C, Librando V, Tosi G, et al. (2013) Infrared microspectroscopy of oral squamous cell carcinoma: spectral signatures of cancer grading, Vib Spectrosc 68: 196-203.

130. Orphanou CM (2015) The detection and discrimination of human body fluids, using ATR FT-IR spectroscopy. Forensic Sci Int 252: e10-e16.

131.Borg A, Birkhed D (1988) Secretion of glucose in human parotid saliva after carbohydrate intake. Scand J Dent Res 96: 551-556.

132.de Almeida PDV, Grégio AMT, Machado MÂN, de Lima AAS, Azevedo LR (2008) Saliva composition and functions: a comprehensive review. J Contemp Dent Pract 9: 72-80.

133.Khajehpour M, Dashnau JL, Vanderkooi JM (2006) Infrared spectroscopy used to evaluate glycosylation of proteins. Anal Biochem 348: 40-48.

134.Baker MJ, Byrne HJ, Chalmers J, Gardner P, Goodacre R, et al. (2018) Clinical applications of infrared and Raman 
spectroscopy: state of play and future challenges. Analyst 143: $1735-1757$.

135. Yang W, Xiao X, Tan J, Cai Q (2009) In situ evaluation of breast cancer cell growth with 3D ATR-FTIR spectroscopy. Vib Spectrosc 49: 64-67.

136.Eckel R, Huo H, Guan HW, Hu X, Che X, et al. (2001) Characteristic infrared spectroscopic patterns in the protein bands of human breast cancer tissue. Vib Spectrosc 27: 165173.

137.Kim Y, Rose CA, Liu Y, Ozaki Y, Datta G, et al. (1994) FTIR and near-infrared FT-Raman studies of the secondary structure of insulinotropin in the solid state: $\alpha$-helix to $\beta$-sheet conversion induced by phenol and/or high shear force. J Pharm Sci 83: 1175-1180.

138. Bel'skaya LV, Sarf EA, Gundyrev IA (2019) Study of the IR spectra of the saliva of cancer patients, composition. J Appl Spectrose 85: 1076-1084.

139. Baker MJ, Hussain SR, Lovergne L, Untereiner V, Hughes C, et al. (2016) Developing and understanding biofluid vibrational spectroscopy: a critical review. Chem Soc Rev 45: 1803-1818.

140.Deleris G, Petibois C (2003) Application of FT-IR spectrometry to plasma contents analysis and monitoring. Vib Spectrose 32: 129-136.

141.Petibois C, Cazorla G, Cassaigne A, Perromat A, Deleris G (2001) Plasma protein contents determined by Fouriertransform infrared spectrometry. Clin Chem 47: 730-738.

142.Liesenfeld DB, Habermann N, Owen RW, Scalbert A, Ulrich CM (2013) Review of Mass Spectrometry-Based Metabolomics in Cancer Research. Cancer Epidemiol. Biomarkers Prev 22: 2182-2201.

143. Fiehn O (2002) Metabolomics the link between genotypes and phenotypes. Plant Mol Biol 48: 155-171.

144. Griffin JL, Shockcor JP (2004) Metabolic profiles of cancer cells. Nat Rev Cancer 4: 551-561.

145.Ishikawa S, Sugimoto M, Kitabatake K, Sugano A, Nakamura M, Kaneko M, Iino M (2016) Identification of salivary metabolomic biomarkers for OC screening. Sci Rep 6:31520.

146. Pavlova NN, Thompson CB (2016) The emerging hallmarks of cancer metabolism. Cell Metab 23: 27-47.

147.Zhu J, Thompson CB (2019) Metabolic regulation of cell growth and proliferation. Nat Rev Mol Cell Biol 20: 436-450.

148. Song X, Yang X, Narayanan R, Shankar V, Ethiraj S, et al. (2020) Oral squamous cell carcinoma diagnosed from saliva metabolic profiling. PNAS 2020: 1-7.

149.Casero RA, Stewart TM, Pegg AE (2018) Polyamine metabolism and cancer: Treatments, challenges and opportunities. Nat Rev Cancer 18: 681-695.

150. Sobieszczuk-Nowicka E (2019) Polyamines-A new metabolic switch: Crosstalk with networks involving senescence, crop improvement, and mammalian cancer therapy. Front Plant Sci 10: 859 .

151.Kim S, You S, Hwang D (2011) Aminoacyl-tRNA synthetases and tumorigenesis: More than housekeeping. Nat Rev Cancer 11: 708-718.

152.Park SG, Schimmel P, Kim S (2008) Aminoacyl tRNA synthetases and their connections to disease. Proc Natl Acad Sci USA 105: 11043-11049.

153.Altman BJ, Stine ZE, Dang CV (2016) From Krebs to clinic:
Glutamine metabolism to cancer therapy. Nat Rev Cancer 16: 619-634.

154.Heiden MGV, Cantley LC, Thompson CB (2009) Understanding the Warburg effect: The metabolic requirements of cell proliferation. Science 324: 1029-1033.

155. Wang X (2017) Purine synthesis promotes maintenance of brain tumor initiating cells in glioma. Nat Neurosci 20: 661673.

156. Yin J (2018) Potential mechanisms connecting purine metabolism and cancer therapy. Front Immunol 9: 1697.

157. Ogretmen B (2018) Sphingolipid metabolism in cancer signalling and therapy. Nat Rev Cancer 18: 33-50.

158. Glunde K, Penet MF, Jiang L, Jacobs MA, Bhujwalla JM (2015) Choline metabolismbased molecular diagnosis of cancer: An update. Expert Rev Mol Diagn 15: 735-747.

159.Duffy MJ, Sturgeon CM, Soletormos G, Barak V, Molina R, et al. (2015) Validation of new cancer biomarkers: A position statement from the European group on tumour markers. Clin Chem 61: 809-820.

160.Pérez-sayáns M, Somoza-martín JM, Barros-angueira F, Reboiras-lópez MD, Rey JMG, et al. (2009) Genetic and molecular alterations associated with oral squamous cell cancer (Review). Oncology reports 22: 1277-1282.

161.Boyd NM, Reade PC (1988) Mechanisms of carcinogenesis with particular reference to the oral mucosa. J Oral Pathol 17: 193-201.

162.Hanahan D, Weinberg RA (2000) The hallmarks of cancer. Cell 100: 57-70.

163. Rajeevan MS, Vernon SD, Taysavang N (2001) Validation of array-based gene expression profiles by real-time (kinetic) RT-PCR. J Mol Diagn 3: 26-31.

164.Higuchi R, Fockler C, Dollinger G, Watson R (1993) Kinetic PCR analysis: real-time monitoring of DNA amplification reactions. Biotechnology (NY) 11: 1026-1030.

165. Wittwer CT, Herrmann MG, Moss AA, Rasmussen RP (1997) Continuous fluorescence monitoring of rapid cycle DNA amplification. Biotechniques 22: 130-131, 134-138.

166. Somoza-Martin JM， Garcia-Garcia A， Barros-Angueira F (2005) Gene expression profile in oral squamous cell carcinoma: a pilot study. J Oral Maxillofac Surg 63: 786-792.

167.Uzawa N, Akanuma D, Negishi A (2001) Homozygous deletions on the short arm of chromosome 3 in human oral squamous cell carcinomas. Oral Oncol 37: 351-356.

168.El-Naggar AK, Hurr K, Batsakis JG (1995) Sequential loss of heterozygosity at microsatellite motifs in preinvasive and invasive head and neck squamous carcinoma. Cancer Res 55: 2656-2659.

169. Ohta S, Uemura H, Matsui Y (2009) Alterations of p16 and p14ARF genes and their 9p21 locus in oral squamous cell carcinoma. Oral Surg Oral Med Oral Pathol Oral Radiol Endod 107: 81-91.

170. Gebhart E, Liehr T, Wolff E (2003) Loss of 9p21 is embedded in a complex but consistent pattern of genomic imbalances in oral squamous cell carcinomas. Cytogenet Genome Res 101: 106-112.

171. Moles MAG, Montoya JAG, Avila IR (2008) Bases moleculares de la cancerización de cavidad oral. Av Odontoestomatol 24: 55-60.

172. Brandt B, Meyer-Staeckling S, Schmidt H (2006) Mechanisms 
of EGFR gene transcription modulation: relationship to cancer risk and therapy response. Clin Cancer Res 12: 7252-7260.

173. Silva SD, Perez DE, Alves FA (2008) ErbB2 and fatty acid synthase (FAS) expression in 102 squamous cell carcinomas of the tongue: correlation with clinical outcomes. Oral Oncol 44: 484-490.

174. SchartingerVH, Kacani L,Andrle J(2004) Pharmacodiagnostic value of the HER family in head and neck squamous cell carcinoma. ORL J Otorhinolaryngol Relat Spec 66: 21-26.

175. Vairaktaris E, Goutzanis L, Kalokerinos G (2007) Diabetes increases both N-ras and ets-1 expression during rat oral oncogenesis resulting in enhanced cell proliferation and metastatic potential. In Vivo 21: 615-621.

176.Zhou X, Zhang Z, Yang X (2009) Inhibition of cyclin D1 expression by cyclin D1 shRNAs in human oral squamous cell carcinoma cells is associated with increased cisplatin chemosensitivity. Int J Cancer 124: 483-489.

177. Sathyan KM, Nalinakumari KR, Abraham T, Kannan S (2008) CCND1 polymorphisms (A870G and C1722G) modulate its protein expression and survival in oral carcinoma. Oral Oncol 44: 689-697.

178. Marsit CJ, Black CC, Posner MR, Kelsey KT (2008) A genotypephenotype examination of cyclin D1 on risk and outcome of squamous cell carcinoma of the head and neck. Clin Cancer Res 14: 2371-2377.

179. Kozomara RJ, Brankovic-Magic MV, Jovic NR (2007) Prognostic significance of TP53 mutations in oral squamous cell carcinoma with human papilloma virus infection. Int $\mathrm{J}$ Biol Markers 22: 252-257.

180. Kresty LA, Mallery SR, Knobloch TJ (2002) Alterations of p16(INK4a) and p14(ARF) in patients with severe oral epithelial dysplasia. Cancer Res 62: 5295-5300.

181. Shintani S, Nakahara Y, Mihara M (2001) Inactivation of the p14(ARF), p15(INK4B) and p16(INK4A) genes is a frequent event in human oral squamous cell carcinomas. Oral Oncol 37: 498-504.

182. Van Heerden WF, Swart TJ, Robson B (2001) FHIT RNA and protein expression in oral squamous cell carcinomas. Anticancer Res 21: 2425-2428.

183.Imai T, Toyota M, Suzuki H (2008) Epigenetic inactivation of RASSF2 in oral squamous cell carcinoma. Cancer Sci 99: 958-966.

184. Sidransky D (2002) Emerging molecular markers of cancer. Nat Rev Cancer 2: 210 -219.

185. Hollstein M, Sidransky D, Vogelstein B, Harris CC (1991) p53 mutations in human cancers. Science (Wash DC) 253: 49-53.
186.Liu T, Wahlberg S, Burek E, Lindblom P, Rubio C, et al. (2000) Microsatellite instability as a predictor of a mutation in a DNA mismatch repair gene in familial colorectal cancer. Genes Chromosomes Cancer 27: 17-25.

187. Groden J, Thliveris A, Samowitz W (1991) Identification and characterization of the familial adenomatous polyposis coli gene. Cell 66: 589-600.

188.Lin X, Mattjus P, Pike HM, Windebank AJ, Brown RE (2000) Cloning and expression of glycolipid transfer protein from bovine and porcine brain. J Biol Chem 275: 5104-5110.

189. Rao CS, Chung T, Pike HM, Brown RE (2005) Glycolipid transfer protein interaction with bilayer vesicles: modulation by changing lipid composition. Biophys J 89: 4017-4028.

190.Looman C, Hellman L, Abrink MA (2004) novel KruppelAssociated Box identified in a panel of mammalian zinc finger proteins. Mamm Genome 15: 35-40.

191. Chang CD, Ottavio L, Travali S, Lipson KE, Baserga R (1990) Transcriptional and posttranscriptional regulation of the proliferating cell nuclear antigen gene. J Mol Cell Biol 10: 3289-3296.

192.Rundle DR, Gorbsky G, Leonidas T (2004) PKD2 interacts and co-localizes with mDial to mitotic spindles of dividing cells: role of mDia1 in PKD2 localization to mitotic spindles. J Biol Chem 279: 29728-29739.

193.Cook BD, Dynek JN, Chang W, Shostak G, Smith S (2002) Role for the related poly (ADP-Ribose) polymerases tankyrase 1 and 2 at human telomeres. J Mol Cell Biol 22: 332-342.

194. Kaminker PG, Kim SH, Taylor RD, Zebarjadian Y, Funk WD, et al. (2001) TANK2, a new TRF1- associated poly (ADPribose) polymerase, causes rapid induction of cell death upon overexpression. J Biol Chem 276: 35891-35899.

195.Guo Q, Xie J, Dang CV, Liu ET, Bishop JM (1998) Identification of a large Myc-binding protein that contains RCC1-like repeats. PNAS USA 95: 9172-9177.

196.Pierre SC, Hausler J, Birod K, Geisslinger G, Scholich K (2004) PAM mediates sustained inhibition of cAMP signaling by sphingosine-1-phosphate. EMBO Journal 23: 3031-3040.

197. Nielsen BB, Kastrup JS, Rasmussen H, Holtet TL, Graversen JH, et al. (1997) Crystal structure of tetranectin, a trimeric plasminogen-binding protein with an alpha-helical coiled coil. FEBS Lett 412: 388-396.

198. Sajan T, Murthy S, Krishnankutty R, Mitra J (2019) A rapid, early detection of oral squamous cell carcinoma: Real time PCR based detection of tetranectin. Mol Biol Res Commun 8: 33-40.
Copyright: (@2021 Bimalka Seneviratne, et al. This is an open-access article distributed under the terms of the Creative Commons Attribution License, which permits unrestricted use, distribution, and reproduction in any medium, provided the original author and source are credited. 